\title{
The effect of $\mathrm{pCO}_{2}$ on carbon acquisition and intracellular assimilation in four marine diatoms
}

\author{
Scarlett Trimborn *, Dieter Wolf-Gladrow, Klaus-Uwe Richter, Björn Rost \\ Alfred Wegener Institute for Polar and Marine Research, Am Handelshafen 12, 27570 Bremerhaven, Germany
}

\section{A R T I C L E I N F O}

\section{Article history:}

Received 26 November 2008

Received in revised form 26 May 2009

Accepted 29 May 2009

\section{Keywords}

CCM

${ }^{13} \mathrm{C}$ fractionation

CA

$\mathrm{C}_{4}$ photosynthesis

PEPC

RubisCO

\begin{abstract}
A B S T R A C T
The effect of $\mathrm{pCO}_{2}$ on carbon acquisition and intracellular assimilation was investigated in the three bloomforming diatom species, Eucampia zodiacus (Ehrenberg), Skeletonema costatum (Greville) Cleve, Thalassionema nitzschioides (Grunow) Mereschkowsky and the non-bloom-forming Thalassiosira pseudonana (Hust.) Hasle and Heimdal. In vivo activities of carbonic anhydrase (CA), photosynthetic $\mathrm{O}_{2}$ evolution, $\mathrm{CO}_{2}$ and $\mathrm{HCO}_{3}^{-}$ uptake rates were measured by membrane-inlet mass spectrometry (MIMS) in cells acclimated to $\mathrm{pCO}_{2}$ levels of 370 and $800 \mu \mathrm{atm}$. To investigate whether the cells operate a $\mathrm{C}_{4}$-like pathway, activities of ribulose1,5-bisphosphate carboxylase (RubisCO) and phosphoenolpyruvate carboxylase (PEPC) were measured at the mentioned $\mathrm{pCO}_{2}$ levels and a lower $\mathrm{pCO}_{2}$ level of $50 \mu \mathrm{atm}$. In the bloom-forming species, extracellular $\mathrm{CA}$ activities strongly increased with decreasing $\mathrm{CO}_{2}$ supply while constantly low activities were obtained for T. pseudonana. Half-saturation concentrations $\left(K_{1 / 2}\right)$ for photosynthetic $\mathrm{O}_{2}$ evolution decreased with decreasing $\mathrm{CO}_{2}$ supply in the two bloom-forming species $S$. costatum and $T$. nitzschioides, but not in T. pseudonana and E. zodiacus. With the exception of $S$. costatum, maximum rates $\left(V_{\max }\right)$ of photosynthesis remained constant in all investigated diatom species. Independent of the $\mathrm{pCO}_{2}$ level, PEPC activities were significantly lower than those for RubisCO, averaging generally less than 3\%. All examined diatom species operate highly efficient $\mathrm{CCMs}$ under ambient and high $\mathrm{pCO}_{2}$, but differ strongly in the degree of regulation of individual components of the CCM such as $C_{\mathrm{i}}$ uptake kinetics and extracellular CA activities. The present data do not suggest $\mathrm{C}_{4}$ metabolism in the investigated species.
\end{abstract}

(c) 2009 Elsevier B.V. All rights reserved.

\section{Introduction}

Diatoms are a diverse and ecologically very important group contributing up to $40 \%$ of the oceans primary production (Nelson et al., 1995). Among the large diversity in this group, bloom-forming diatoms play a major role in determining the downward transport of organic carbon from surface waters to the deep ocean (Buesseler, 1998). Numerous diatom species are known to bloom frequently along continental margins and in upwelling regions where the nutrient availability is high (Smetacek, 1999). The occurrence of high diatom abundances in nutrient-rich waters has been related to several physiological adaptations. Mostly centric diatoms have evolved a vacuole that allows accumulating nutrients in excess of its immediate growth requirements and therewith deprives competing taxa of these essential resources (Raven, 1997; Falkowski et al., 2004). Such storage capacity permits these diatoms to maintain high division rates for several generations after a pulse of nutrients.

\footnotetext{
* Corresponding author. Alfred Wegener Institute for Polar and Marine Research, Am Handelshafen 12, 27570 Bremerhaven, Germany. Tel.: +49 4714831 1038; fax: +4947148312020 .

E-mail address: scarlett.trimborn@awi.de (S. Trimborn).
}

A prerequisite for high growth rates and the ability to form blooms is an efficient and regulated acquisition of inorganic carbon $\left(C_{\mathrm{i}}\right)$ that compensates for the catalytic inefficiency of their carbon fixing enzyme ribulose-1,5-bisphosphate carboxylase/oxygenase (RubisCO). This highly conserved enzyme requires $\mathrm{CO}_{2}$ as substrate, but it has only a poor affinity for this substrate $\left(K_{\mathrm{M}}\right.$ of $20-70 \mu \mathrm{mol} \mathrm{L}{ }^{-1}$, Badger et al., 1998). Therefore, at present-day $\mathrm{CO}_{2}$ concentrations in seawater ranging between 8 and $20 \mu \mathrm{mol} \mathrm{L}^{-1}$ photosynthesis of phytoplankton may suffer from $\mathrm{CO}_{2}$ limitation. To circumvent this, marine diatoms as well as other phytoplankton taxa operate the so-called carbon concentrating mechanisms (CCMs) that enrich $\mathrm{CO}_{2}$ at the catalytic site of RubisCO (Giordano et al., 2005; Price et al., 2007; Roberts et al., 2007a). CCMs involve active uptake of $\mathrm{CO}_{2}$ or $\mathrm{HCO}_{3}^{-}$or both. The enzyme carbonic anhydrase (CA), which accelerates the otherwise slow interconversion between $\mathrm{HCO}_{3}^{-}$and $\mathrm{CO}_{2}$, can be located both inside the cell and at the cell surface. Since the loss of the accumulated inorganic carbon $\left(C_{\mathrm{i}}\right)$ by $\mathrm{CO}_{2}$ efflux increases energetic costs and/or decreases the efficiency of a CCM, the ability of a cell to minimize the $\mathrm{CO}_{2}$ efflux is also an important component of the CCM (Raven and Lucas, 1985; Rost et al., 2006a,b).

Studying the modes of $C_{\mathrm{i}}$ acquisition and assimilation has gained increasing interest given the need to understand the potential effect of rising atmospheric $\mathrm{CO}_{2}$ levels on overall primary productivity or 
phytoplankton species composition (e.g. Raven and Johnston, 1991; Tortell et al., 2008). The group of diatoms and especially bloom-forming representatives are of particular interest because they strongly influence the vertical fluxes of particular material (Buesseler, 1998). By comparing the apparent half-saturation concentrations $\left(K_{1 / 2}\right)$ for photosynthetic $\mathrm{CO}_{2}$ fixation with the half-saturation constant $\left(K_{\mathrm{M}}\right)$ of RubisCO, the presence and the efficiency of a CCM can be assessed (Badger et al., 1998). Relatively efficient CCMs were found in diatoms (Burns and Beardall, 1987; Colman and Rotatore, 1995; Mitchell and Beardall, 1996; Burkhardt et al., 2001; Rost et al., 2003; Trimborn et al., 2008) especially in comparison to other phytoplankton taxa, and these processes are strongly regulated as a function of $\mathrm{CO}_{2}$ supply (Burkhardt et al., 2001; Rost et al., 2003; Trimborn et al., 2008).

Despite this common feature, diatoms appear to display a high diversity in the way they acquire $C_{\mathrm{i}}$. It could be shown that diatoms are able to take up both $\mathrm{CO}_{2}$ and $\mathrm{HCO}_{3}^{-}$(Burns and Beardall, 1987; Colman and Rotatore, 1995; Rotatore et al., 1995; Mitchell and Beardall, 1996; Korb et al., 1997; Burkhardt et al., 2001; Rost et al., 2003, 2007; Trimborn et al., 2008), but species differ strongly in the extent to which both carbon sources are utilized (Burkhardt et al., 2001; Rost et al., 2003; Trimborn et al., 2008). Regarding activities of extracellular CA (eCA), diatom species also differed strongly in these studies ranging from activities close to detection limit to some of the highest reported values (Burns and Beardall, 1987; Colman and Rotatore, 1995; Mitchell and Beardall, 1996; Nimer et al., 1997; Burkhardt et al., 2001; Rost et al., 2003; Trimborn et al., 2008). As pointed out by Trimborn et al. (2008), predominant uptake of $\mathrm{HCO}_{3}^{-}$or $\mathrm{CO}_{2}$ generally correlated with high or low eCA activities, respectively. Martin and Tortell (2008) also found this positive correlation between high eCA activities and direct $\mathrm{HCO}_{3}^{-}$uptake in 17 diatom species. Opposing the common notion that eCA functions to supply $\mathrm{CO}_{2}$ to the uptake systems (Elzenga et al., 2000; Sültemeyer, 1998; Colman et al., 2002), Trimborn et al. (2008) suggested that the presence or absence of eCA allows for a more efficient $C_{\mathrm{i}}$ recycling in $\mathrm{HCO}_{3}^{-}$and $\mathrm{CO}_{2}$ users, respectively.

Also controversially discussed in diatoms is the potential role of $\mathrm{C}_{4}{ }^{-}$ like photosynthetic pathway within carbon assimilation (Reinfelder et al., 2000, 2004; Granum et al., 2005; Roberts et al., 2007a,b; Kroth et al., 2008). This involves the formation of oxaloacetate and malate by phosphoenolpyruvate carboxylase (PEPC), which has the advantage over RubisCO of a high affinity to its carbon source $\mathrm{HCO}_{3}^{-}$along with insensitivity to $\mathrm{O}_{2}$. While evidence for such a pathway comes from experiments with the marine diatom Thalassiosira weissflogii (Reinfelder et al., 2000, 2004; Morel et al., 2002), Roberts et al. (2007b) demonstrated that this species relies on an intermediate $C_{3}-C_{4}$ pathway. For Thalassiosira pseudonana, RT-PCR as well as ${ }^{14} \mathrm{C}$ short-term labelling experiments could not support $\mathrm{C}_{4}$-like metabolism (Granum et al., 2005; Roberts et al., 2007b). In contrast, using gene transcript analysis and inhibitor studies McGinn and Morel (2008) concluded that a $\mathrm{C}_{4}$-like pathway would operate in T. pseudonana and Phaeodactylum tricornutum. The possibility of a $\mathrm{C}_{4}$-like pathway in other diatom species has not yet been investigated.

The aim of this study was to improve our understanding of the modes of carbon acquisition and to clarify whether a $\mathrm{C}_{4}$-like pathway may operate in four diatom species. As bloom-forming representatives we chose Eucampia zodiacus (Hobson and McQuoid, 1997), Skeletonema costatum (Marshall, 1976; Hobson and McQuoid, 1997) and Thalassionema nitzschioides (Marshall, 1976, 1978; Edwards et al., 2005) and as non-bloom-forming species the coastal marine diatom T. pseudonana for which the genome has been recently sequenced (Armbrust et al., 2004). Photosynthetic $\mathrm{O}_{2}$ evolution as well as $\mathrm{CO}_{2}$ and $\mathrm{HCO}_{3}^{-}$uptake were quantified during steady-state photosynthesis by means of a membrane-inlet mass spectrometry (MIMS). To characterise the CCM of each species further, measurements of intracellular and extracellular CA activities were performed by monitoring ${ }^{18} \mathrm{O}$ exchange from doubly labelled ${ }^{13} \mathrm{C}^{18} \mathrm{O}_{2}$. RubisCO and PEPC activities were measured to provide insights into the biochemical mechanisms of intracellular C assimilation.

\section{Material and methods}

\subsection{Culture and experimental conditions}

T. nitzschioides and E. zodiacus (both species isolated from the North Sea by Anne Schwaderer in 2004), S. costatum (CCMP 1332) and T. pseudonana (CCMP 1335) were grown at $15^{\circ} \mathrm{C}$ in semi-continuous dilute batch cultures using sterile-filtered $(0.2 \mu \mathrm{m})$ unbuffered seawater, enriched with nutrients, silicate, trace metals and vitamins according to F/2 medium (Guillard and Ryther, 1962). Experiments were carried out using a light:dark cycle of 16:8 h at an incident light intensity of $200 \mu \mathrm{mol}$ photons $\mathrm{m}^{-2} \mathrm{~s}^{-1}$. Cultures as well as the respective dilution media were continuously sparged with air containing $\mathrm{CO}_{2}$ partial pressures $\left(\mathrm{pCO}_{2}\right)$ of $50,370,800 \mu$ atm resulting in $\mathrm{pH}$ values of 8.9, 8.2, and 7.9, respectively, on the National Bureau of Standards (NBS) scale. $\mathrm{CO}_{2}$ gas mixtures were generated with gas-mixing pumps (Woesthoff $\mathrm{GmbH}$, Bochum, Germany), using $\mathrm{CO}_{2}$-free air (Nitrox $\mathrm{CO}_{2} \mathrm{RP280}$, Domnick Hunter ltd., Willich, Germany), pure $\mathrm{CO}_{2}$ (Air Liquide Deutschland ltd., Germany), or ambient air, respectively. pH was measured using a pH-meter (WTW, model pMX 3000/pH, Weilheim, Germany) that was calibrated (2-point calibration) on a daily basis. Daily dilutions with the corresponding acclimation media ensured that the $\mathrm{pH}$ level remained constant and that the cells stayed in the mid-exponential growth phase. Cultures in which the $\mathrm{pH}$ had shifted significantly $(>0.05 \mathrm{U})$ in comparison to cell-free medium at the respective $\mathrm{pCO}_{2}$ were excluded from further analysis.

\subsection{Determination of seawater carbonate chemistry}

Alkalinity samples were taken from the filtrate (Whatman GFF filter, $\sim 0.6 \mu \mathrm{m}$ ), stored in $300-\mathrm{mL}$ borosilicate flasks at $4{ }^{\circ} \mathrm{C}$ and measured by potentiometric titration with an average precision of $8 \mu \mathrm{mol} \mathrm{kg} \mathrm{kg}^{-1}$ (Brewer et al., 1986). Total alkalinity was calculated from linear Gran Plots (Gran, 1952). The carbonate system was calculated from alkalinity, $\mathrm{pH}$, silicate, phosphate, temperature, and salinity using the CO2Sys program (Lewis and Wallace, 1998). Equilibrium constants of Mehrbach et al. (1973) refitted by Dickson and Millero (1987) were chosen. The parameters of the carbonate system for the respective treatments are given in Table 1.

\subsection{Sampling}

After acclimation to 370 and $800 \mu$ atm for at least 3 days, cells were harvested by gentle filtration over a $3 \mu \mathrm{m}$ membrane filter (Isopore, Millipore) 4 to $8 \mathrm{~h}$ after the beginning of the photoperiod to allow photosynthesis and CCM activity to be fully induced. Subsequently, the cells were washed with $\mathrm{CO}_{2}$-free $\mathrm{F} / 2$ medium buffered with $50 \mathrm{mmol} \mathrm{L}{ }^{-1}$ 2-[4-(2-Hydroxyethyl)-1-piperazinyl]ethanesulfonic acid (HEPES, pH 8.0). The samples were then used for measuring inorganic carbon $\left(C_{\mathrm{i}}\right)$ fluxes and CA activities with the MIMS. Samples for determination of chlorophyll $a(\mathrm{Chl} a)$ concentration were taken after the measurements and stored at $-80^{\circ} \mathrm{C}$. Chl $a$ was subsequently

\section{Table 1}

Parameters of the seawater carbonate system were calculated from alkalinity, $\mathrm{pH}$, silicate, phosphate, temperature, and salinity using the CO2Sys program (Lewis and Wallace, 1998).

\begin{tabular}{|c|c|c|c|c|c|}
\hline & $\mathrm{pCO}_{2}$ & $\mathrm{CO}_{2}$ & DIC & $\mathrm{TA}$ & $\mathrm{pH}$ \\
\hline & 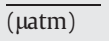 & $\overline{\left(\mu \mathrm{mol} \mathrm{kg} \mathrm{kg}^{-1}\right)}$ & $\overline{\left(\mu \mathrm{mol} \mathrm{kg}{ }^{-1}\right)}$ & $\left.\overline{(\mu \mathrm{Eq} \mathrm{kg}}{ }^{-1}\right)$ & $\overline{(\mathrm{NBS})}$ \\
\hline High $\mathrm{pCO}_{2}$ & $803 \pm 8$ & $31 \pm 0.3$ & $2176 \pm 21$ & $2309 \pm 21$ & $7.90 \pm 0.03$ \\
\hline Ambient $\mathrm{pCO}_{2}$ & $369 \pm 3$ & $14 \pm 0.1$ & $2059 \pm 19$ & $2317 \pm 15$ & $8.20 \pm 0.03$ \\
\hline Low $\mathrm{pCO}_{2}$ & $51 \pm 0.2$ & $1.9 \pm 0.03$ & $1567 \pm 40$ & $2297 \pm 9$ & $8.85 \pm 0.03$ \\
\hline
\end{tabular}

Values represent the means of at least twelve replicate incubations $( \pm S D)$. 
extracted in $10 \mathrm{~mL}$ acetone (overnight in darkness, at $4{ }^{\circ} \mathrm{C}$ ) and determined with a Turner Designs Fluorometer (Model 10-000 R, Mt. View, Canada).

\subsection{Determination of CA activity}

Activity of extracellular and intracellular CA was determined by measuring the loss of ${ }^{18} \mathrm{O}$ from doubly labelled ${ }^{13} \mathrm{C}^{18} \mathrm{O}_{2}$ to water caused by the interconversion of $\mathrm{CO}_{2}$ and $\mathrm{HCO}_{3}^{-}$(Silverman, 1982). The determination of CA activity was performed with a sector field multicollector mass spectrometer (Isoprime, GV Instruments, Manchester, UK) via a gas-permeable polytetrafluoroethylene membrane (PTFE, $0.01 \mathrm{~mm}$ ) inlet system. The reaction sequence of ${ }^{18} \mathrm{O}$ loss from initial ${ }^{13} \mathrm{C}^{18} \mathrm{O}^{18} \mathrm{O}(\mathrm{m} / z=49)$, via the intermediate ${ }^{13} \mathrm{C}^{18} \mathrm{O}^{16} \mathrm{O}$ $(m / z=47)$ to the final molecule ${ }^{13} \mathrm{C}^{16} \mathrm{O}^{16} \mathrm{O}(\mathrm{m} / z=45)$ was recorded continuously. The ${ }^{18} \mathrm{O}$ enrichment was calculated as:

$$
\begin{aligned}
{ }^{18} \mathrm{O} \log (\text { enrichment }) & =\log \frac{\left({ }^{13} \mathrm{C}^{18} \mathrm{O}_{2}\right) \times 100}{{ }^{13} \mathrm{CO}_{2}} \\
& =\log \frac{(\mathrm{m} / \mathrm{z} 49) \times 100}{\mathrm{~m} / \mathrm{z} 45+\mathrm{m} / \mathrm{z} 47+\mathrm{m} / \mathrm{z} 49}
\end{aligned}
$$

CA measurements were performed in $8 \mathrm{~mL}$ of $\mathrm{F} / 2$ medium buffered with 50 mmol L ${ }^{-1}$ HEPES ( $\mathrm{pH} \mathrm{8.0)}$ ) at $15{ }^{\circ} \mathrm{C}$. To avoid interference with light-dependent $C_{\mathrm{i}}$ uptake by the cells, all measurements were carried out in the dark (Palmqvist et al., 1994). After adding $\mathrm{NaH}^{13} \mathrm{C}^{18} \mathrm{O}_{3}$ to a final concentration of $1 \mathrm{mmol} \mathrm{L}^{-1}$ and chemical equilibration, the uncatalyzed ${ }^{18} \mathrm{O}$ loss was monitored for about 8 min prior to the addition of cells. Extracellular CA activity (eCA) was calculated from the increasing rate of ${ }^{18} \mathrm{O}$ depletion after the addition of the cells (slope $S_{2}$ ) in comparison to the uncatalyzed reaction (slope $S_{1}$ ) and normalized on a Chl $a$ basis (Badger and Price, 1989):

$U=\frac{\left(S_{2}-S_{1}\right) \times 100}{S_{1} \times \mu \mathrm{g} \operatorname{Chl} a}$

Intracellular CA activity was determined in the presence of $100 \mu \mathrm{mol} \mathrm{L} \mathrm{L}^{-1}$ dextran-bound sulfonamide (DBS), an inhibitor of eCA. The drop in the $\log$ (enrichment) was calculated by extrapolation of $S_{2}$ back to the time of cell injection ( $\Delta$ as defined by Palmqvist et al., 1994). Values of $\Delta$ are expressed in arbitrary units per $\mu \mathrm{g}$ Chl $a$. Chl $a$ concentrations in CA assays ranged from 0.11 to $1.16 \mu \mathrm{g} \mathrm{mL}{ }^{-1}$.

\subsection{Determination of net photosynthesis, $\mathrm{CO}_{2}$ and $\mathrm{HCO}_{3}^{-}$uptake}

The $C_{\mathrm{i}}$ fluxes were determined during steady-state photosynthesis with the same membrane-inlet mass spectrometer as for the CA measurements. The method established by Badger et al. (1994) uses the chemical disequilibrium between $\mathrm{CO}_{2}$ and $\mathrm{HCO}_{3}^{-}$fluxes during lightdependent $C_{\mathrm{i}}$ uptake to differentiate between $\mathrm{CO}_{2}$ and $\mathrm{HCO}_{3}^{-}$fluxes across the plasmalemma. $C_{\mathrm{i}}$ flux estimates are based on simultaneous measurements of $\mathrm{O}_{2}$ and $\mathrm{CO}_{2}$ during consecutive light and dark intervals. During dark intervals, known amounts of $C_{\mathrm{i}}$ are added to measure rates as a function of $\mathrm{CO}_{2}$ and $\mathrm{HCO}_{3}^{-}$concentrations. Rates of $\mathrm{O}_{2}$ consumption in the dark and $\mathrm{O}_{2}$ evolution in the light provide a direct estimate of respiration and net $C_{\mathrm{i}}$ fixation under the assumption of a respiratory quotient of 1 and a photosynthetic quotient of 1.1 to convert $\mathrm{O}_{2}$ fluxes into $C_{\mathrm{i}}$ fluxes (e.g. Asmus, 1982; Mills and Wilkinson, 1986; Badger et al., 1994; Wolfstein and Hartig, 1998; Rost et al., 2007). Net $\mathrm{CO}_{2}$ uptake is calculated from the steady-state rate of $\mathrm{CO}_{2}$ depletion at the end of the light period, corrected for the $\mathrm{CO}_{2} / \mathrm{HCO}_{3}^{-}$interconversion in the medium. The $\mathrm{HCO}_{3}^{-}$uptake is derived by a mass balance equation, i.e. the difference between net $C_{\mathrm{i}}$ fixation and net $\mathrm{CO}_{2}$ uptake. All measurements were performed in initially $\mathrm{CO}_{2}$-free $\mathrm{F} / 2$ medium buffered with $50 \mathrm{mmol} \mathrm{L}^{-1}$ HEPES ( $\mathrm{pH} \mathrm{8.0)}$ ) at $15{ }^{\circ} \mathrm{C}$. The presence of
DBS ( $100 \mu \mathrm{mol} \mathrm{L}^{-1}$ ) ensured the complete inhibition of any eCA activity in all tested species (data not shown). Light and dark intervals during the assay lasted for $6 \mathrm{~min}$. The incident photon flux density was $300 \mu \mathrm{mol}$ photons $\mathrm{m}^{-2} \mathrm{~s}^{-1}$. Further details on the method and calculations are given in Badger et al. (1994) and Rost et al. (2007). Chl a concentrations in the assay ranged from 0.54 to $1.58 \mu \mathrm{gL}^{-1}$.

\subsection{Carbon isotope fractionation}

Samples for particulate organic carbon (POC) were filtered onto precombusted $\left(500{ }^{\circ} \mathrm{C}, 12 \mathrm{~h}\right)$ GFF filters $(\sim 0.6 \mu \mathrm{m})$ and stored in precombusted $\left(500^{\circ} \mathrm{C}, 12 \mathrm{~h}\right)$ Petri dishes at $-20^{\circ} \mathrm{C}$. Prior to analysis, POC filters were fumed with $\mathrm{HCl}$ for $2 \mathrm{~h}$ to remove all inorganic carbon. POC and related $\delta^{13} \mathrm{C}$ values were subsequently measured in duplicate on an EA mass spectrometer (ANCA-SL 2020, Sercon Ltd., Crewe, UK), with a precision of $\pm 0.5 \%$, respectively. The isotopic composition is reported relative to the PeeDee belemnite standard (PDB):

$\delta^{13} \mathrm{C}_{\text {Sample }}=\left[\frac{\left({ }^{13} \mathrm{C} /{ }^{12} \mathrm{C}\right)_{\text {Sample }}}{\left({ }^{13} \mathrm{C} /{ }^{12} \mathrm{C}\right)_{\mathrm{PDB}}}-1\right] \times 1000$

Isotope fractionation during POC formation $\left(\varepsilon_{\mathrm{p}}\right)$ was calculated relative to the isotopic composition of $\mathrm{CO}_{2}$ in the medium (Freeman and Hayes, 1992):

$\varepsilon_{\mathrm{p}}=\frac{\delta^{13} \mathrm{C}_{\mathrm{CO}_{2}}-\delta^{13} \mathrm{C}_{\mathrm{POC}}}{1+\frac{\delta^{13} \mathrm{C}_{\mathrm{POC}}}{1000}}$

To determine isotopic composition of DIC $\left(\delta^{13} \mathrm{C}_{\mathrm{DIC}}\right)$, samples were sterile-filtered $(0.2 \mu \mathrm{m})$, fixed with $\mathrm{HgCl}_{2}\left(\sim 140 \mathrm{mg} \mathrm{L^{-1 }}\right.$ final concentration), and stored at $4{ }^{\circ} \mathrm{C}$. Measurements of $\delta^{13} \mathrm{C}_{\mathrm{DIC}}$ were performed with a Finnegan mass spectrometer (MAT 252) at a precision of $\delta^{13} \mathrm{C}= \pm 0.05 \%$. The isotopic composition of $\mathrm{CO}_{2}$ $\left(\delta^{13} \mathrm{C}_{\mathrm{CO} 2}\right)$ was calculated from $\delta^{13} \mathrm{C}_{\mathrm{DIC}}$, making use of a mass balance relation (see Zeebe and Wolf-Gladrow, 2001):

$$
\delta^{13} \mathrm{C}_{\mathrm{HCO}_{3}^{-}}=\frac{\delta^{13} \mathrm{C}_{\mathrm{DIC}}[\mathrm{DIC}]-\left(\varepsilon_{\mathrm{a}}\left[\mathrm{CO}_{2}\right]+\varepsilon_{\mathrm{b}}\left[\mathrm{CO}_{3}^{2-}\right]\right)}{\left(1+\varepsilon_{\mathrm{a}} \times 10^{-3}\right)\left[\mathrm{CO}_{2}\right]+\left[\mathrm{HCO}_{3}^{-}\right]+\left(1+\varepsilon_{\mathrm{b}} \times 10^{-3}\right)\left[\mathrm{CO}_{3}^{2-}\right]}
$$

$\delta^{13} \mathrm{C}_{\mathrm{CO}_{2}}=\delta^{13} \mathrm{C}_{\mathrm{HCO}_{3}^{-}}\left(1+\varepsilon_{\mathrm{a}} \times 10^{-3}\right)+\varepsilon_{\mathrm{a}}$

Temperature-dependent fractionation factors between $\mathrm{CO}_{2}$ and $\mathrm{HCO}_{3}^{-}\left(\varepsilon_{\mathrm{a}}\right)$ as well as $\mathrm{HCO}_{3}^{-}$and $\mathrm{CO}_{3}^{2-}\left(\varepsilon_{\mathrm{b}}\right)$ are given by Mook (1986) and Zhang et al. (1995), respectively.

\subsection{Determination of RubisCO and PEPC activities}

The activities of RubisCO and PEPC were determined using ${ }^{14} \mathrm{C}$-based assays modified from Descolas-Gros and Oriol (1992), MacIntyre et al. (1997), Reinfelder et al. (2000), and Tortell et al. (2006). The assays measure the rate of ${ }^{14} \mathrm{C}$ incorporation into organic (acid stable) carbon products following the addition of $\mathrm{H}^{14} \mathrm{CO}_{3}^{-} /{ }^{14} \mathrm{CO}_{2}$ and ribulose bisphosphate (RuBP) or phosphoenolpyruvate (PEP). In the present study, we largely followed the protocol described by Tortell et al. (2006) with a few modifications.

Cells acclimated to 50, 370, and $800 \mu$ atm were concentrated by filtration over a $3 \mu \mathrm{m}$ membrane filter (Isopore, Millipore). Subsequently, $15 \mathrm{~mL}$ of the concentrated cell suspension was transferred to a falcon tube and placed on ice. The samples were then concentrated by centrifugation at $4000 \mathrm{rpm}$ (centrifuge Jouan, Model BR4i, Saint Herblain, France) for $10 \mathrm{~min}$ at $0{ }^{\circ} \mathrm{C}$. The pellet was resuspended with $2 \mathrm{~mL}$ ice-cold extraction/ assay buffer and transferred into a $2 \mathrm{~mL}$ Apex vial. The buffer, modified 


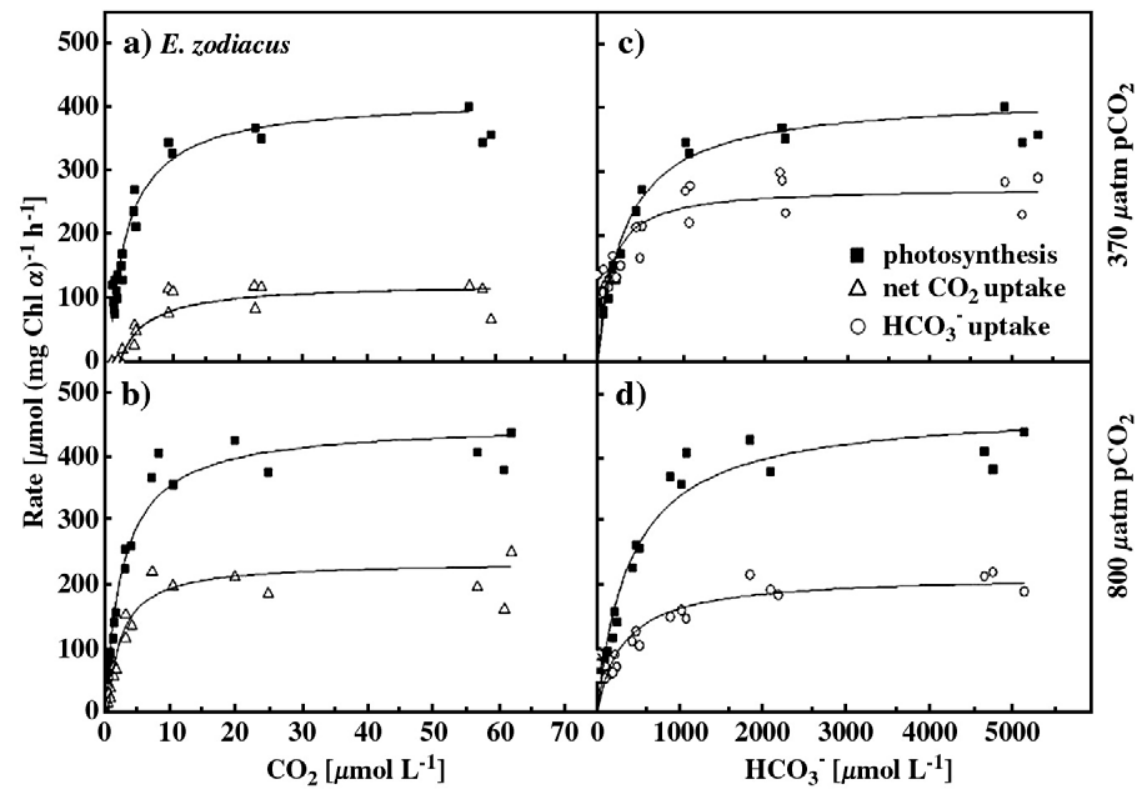

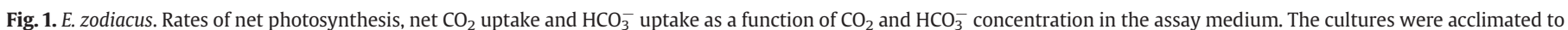
$370 \mu \mathrm{atm}(\mathrm{a}, \mathrm{b})$ and $800 \mu \mathrm{atm}(\mathrm{c}, \mathrm{d})$ of $\mathrm{CO}_{2}$ for at least $3 \mathrm{~d}$. Michaelis-Menten fits were obtained from at least three individual measurements.

from Macintyre et al. (1997) contained $50 \mathrm{mmol} \mathrm{L}^{-1} \mathrm{~N}, \mathrm{~N}-\mathrm{Bis}(2-$ hydroxyethyl) glycine (BICINE, $\mathrm{pH} 7.5), 1 \mathrm{mmol} \mathrm{L}^{-1}$ ethylenediaminetetraacetic acid (EDTA), $10 \mathrm{mmol} \mathrm{L}^{-1} \mathrm{MgCl}_{2}, 1.5 \mathrm{~mol} \mathrm{~L}^{-1}$ glycerol, $10 \mathrm{mmol}$ $\mathrm{L}^{-1} \mathrm{NaHCO}_{3}, 5 \mathrm{mg} \mathrm{L} \mathrm{L}^{-1}$ bovine serum albumin, $0.2 \%$ Triton-X, and $5 \mathrm{mmol} \mathrm{L}^{-1}$ dithiotrietol (DTT). The samples were then homogenized in a glass grinding tube, which was placed in an ice-containing tumbler, with a rotating glass pestle (EUROSTAR digital, IKA-Werke, Staufen, Germany) at $1000 \mathrm{rpm}$ for 3 intervals of $30 \mathrm{~s}$. Subsequently, samples were sonicated (Branson Sonifier 450, Schwäbisch Gmünd, Germany) with a microtip at $70 \%$ duty cycle for 3 intervals of $30 \mathrm{~s}$ at $-2{ }^{\circ} \mathrm{C}$. Crude cell extracts were then clarified by centrifugation (Centrifuge Hettich, Mikro 22R, Schnakenberg, Germany) at $14,000 \mathrm{rpm}$ for $30 \mathrm{~s}$ at $0{ }^{\circ} \mathrm{C}$, and the supernatants retained for enzyme assays.

After extraction, seven $200 \mu \mathrm{L}$ aliquots were taken from the supernatant and dispensed into a microtip, two replicates each for blank, RubisCO and PEPC activity. Then, samples were preincubated over 15 min in the dark leading to the depletion of residual RuBP and PEP in the homogenates. With the exception of the blank, $20 \mu \mathrm{L}$ of either the RuBP stock ( $23 \mathrm{mmol} \mathrm{L}^{-1}$ ) or the PEP stock ( $50 \mathrm{mmol} \mathrm{L}^{-1}$ ) was added to the subsamples. Stock solutions of RuBP and PEP were both stored frozen at $-20^{\circ} \mathrm{C}$. After a 3 -min incubation at $20^{\circ} \mathrm{C}$ in the light (e.g. Macintyre and Geider, 1996; MacIntyre et al., 1997), a $5 \mu \mathrm{Ci}$ spike of $\mathrm{NaH}^{14} \mathrm{CO}_{3}^{-}$ (CFA3, GE Healthcare, Freiburg, Germany) was injected into all samples to initiate ${ }^{14} \mathrm{C}$ fixation. After $30 \mathrm{~min}$, reactions were terminated by the addition of $100 \mu \mathrm{L} \mathrm{HCl}\left(6 \mathrm{~mol} \mathrm{~L}^{-1}\right)$. To remove residual inorganic ${ }^{14} \mathrm{C}$ that had not been fixed, samples were placed in a fume hood on a shaker table and left to degas for at least $24 \mathrm{~h}$. Degassed samples were then transferred into 7-mL scintillation vials and $5 \mathrm{~mL}$ of scintillation cocktail (Ultima Gold AB, Perkin Elmer, Boston, MA, USA) was added. Afterwards,

${ }^{14} \mathrm{C}$ was measured by means of the scintillation counter TriCarb $2100 \mathrm{TR}$

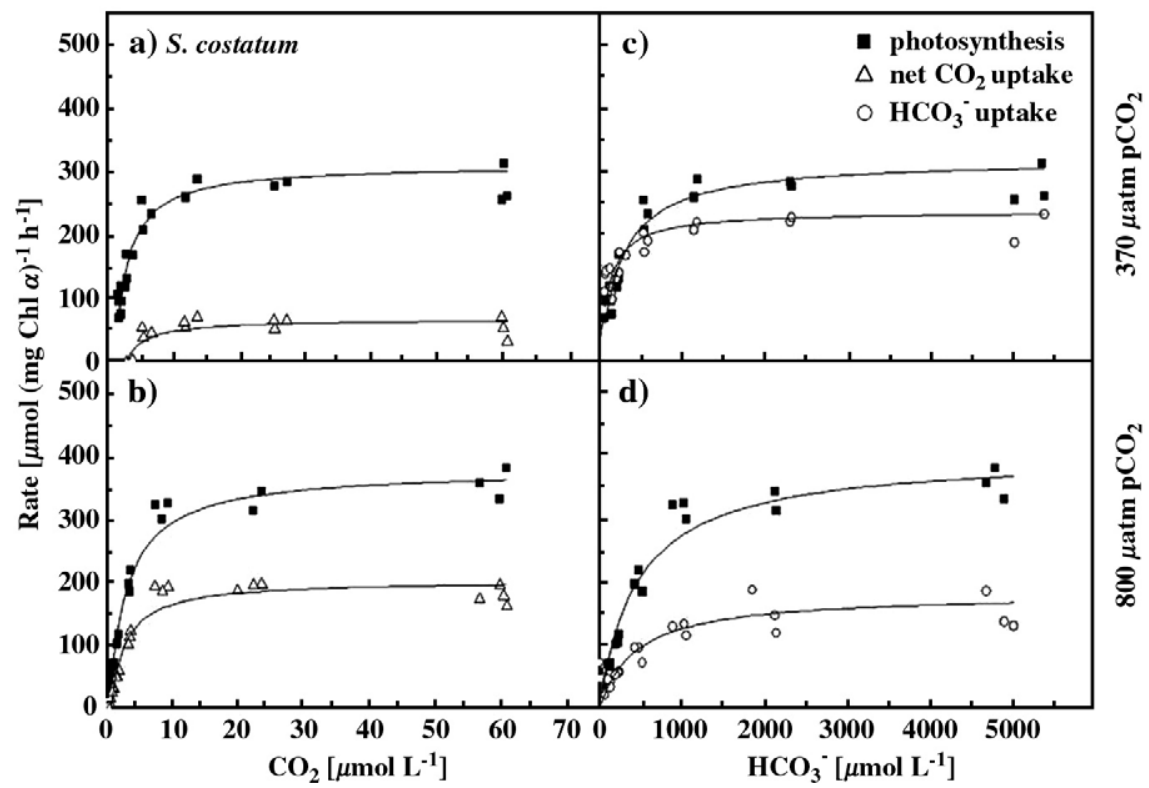

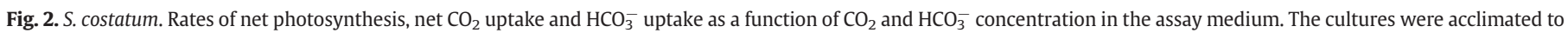
$370 \mu \mathrm{atm}(\mathrm{a}, \mathrm{b})$ and $800 \mu \mathrm{atm}(\mathrm{c}, \mathrm{d})$ of $\mathrm{CO}_{2}$ for at least $3 \mathrm{~d}$. Michaelis-Menten fits were obtained from at least three individual measurements. 


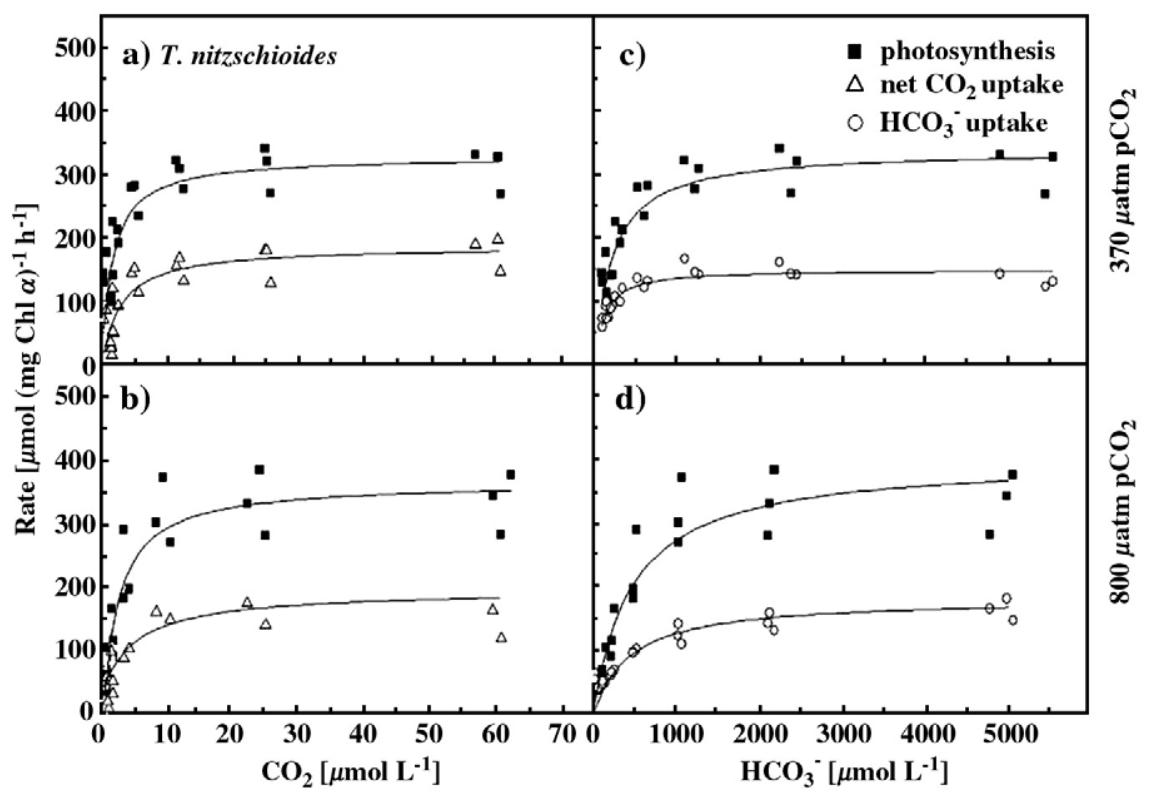

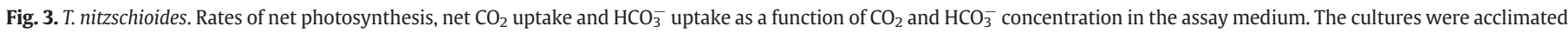
to $370 \mu \mathrm{atm}(\mathrm{a}, \mathrm{b})$ and $800 \mu \mathrm{atm}(\mathrm{c}, \mathrm{d})$ of $\mathrm{CO}_{2}$ for at least $3 \mathrm{~d}$. Michaelis-Menten fits were obtained from at least three individual measurements.

(Canberra, Australia). Radioactivity in the blanks $\left({ }^{14} \mathrm{C}\right.$ added without substrates) was subtracted from all samples.

\section{Results}

\subsection{Photosynthesis and $C_{i}$ fluxes}

Net photosynthesis, net $\mathrm{CO}_{2}$ uptake and $\mathrm{HCO}_{3}^{-}$uptake are shown as a function of $\mathrm{CO}_{2}$ and / or $\mathrm{HCO}_{3}^{-}$concentration for E. zodiacus, S. costatum, T. nitzschioides, and T. pseudonana (Figs. 1-4) acclimated to ambient (370 $\mu \mathrm{atm})$ and high $(800 \mu \mathrm{atm}) \mathrm{pCO}_{2}$ levels. Simultaneous uptake of $\mathrm{CO}_{2}$ and $\mathrm{HCO}_{3}^{-}$during steady-state photosynthesis was observed in all investigated species. The corresponding kinetic parameters such as half- saturation concentrations $\left(K_{1 / 2}\right)$ and maximum rates $\left(V_{\max }\right)$ were obtained from a Michaelis-Menten fit and are summarized in Table 2.

With values between 1.9 and $4.0 \mu \mathrm{mol} \mathrm{CO} \mathrm{L}^{-1}$ for all investigated diatom species, the $K_{1 / 2}\left(\mathrm{CO}_{2}\right)$ values for photosynthesis were about one order of magnitude lower than the $K_{\mathrm{M}}\left(\mathrm{CO}_{2}\right)$ values known for RubisCO in marine diatoms ( 31-41 $\mu \mathrm{mol} \mathrm{CO} 2 \mathrm{~L}^{-1}$, Badger et al., 1998). The $K_{1 / 2}$ values for photosynthesis decreased from $443 \mu \mathrm{mol}$ to $265 \mu \mathrm{mol} \mathrm{DIC} \mathrm{L}{ }^{-1}$ in S. costatum and from $380 \mu \mathrm{mol}$ to $223 \mu \mathrm{mol} \mathrm{DIC} \mathrm{L^{-1 }}$ in T. nitzschioides with decreasing $\mathrm{pCO}_{2}$ in the acclimation ( $t$-test, ${ }^{*} p<0.05$ ), in comparison the $K_{1 / 2}$ values were similar in E. zodiacus and T. pseudonana at both $\mathrm{pCO}_{2}$ levels ( $t$-test, $p>0.05$; Figs. $1-4$, Table 2 ). The $V_{\max }$ of photosynthesis remained constant in E. zodiacus, T. nitzschioides and T. pseudonana ( $t$-test, $p>0.05$ ) while $V_{\max }$ increased with increasing $\mathrm{pCO}_{2}$ in S. costatum (t-test, ${ }^{*} p<0.05$; Figs. 1-4, Table 2).

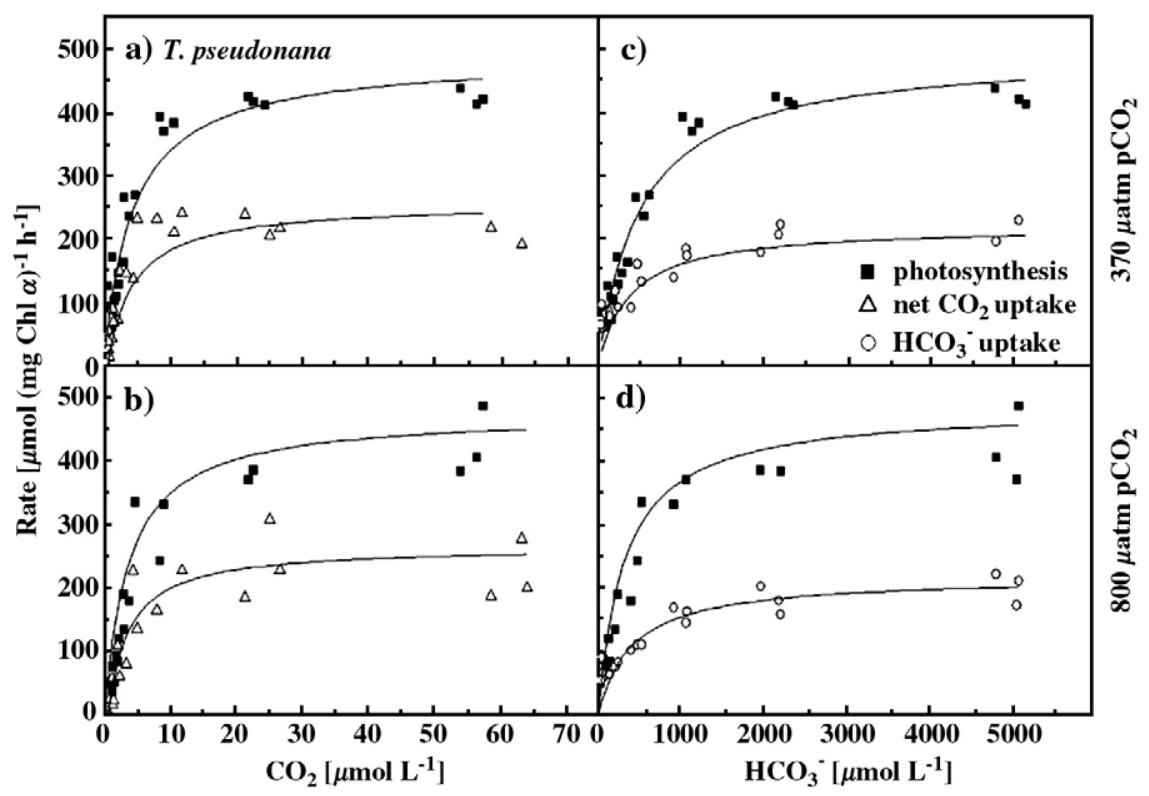

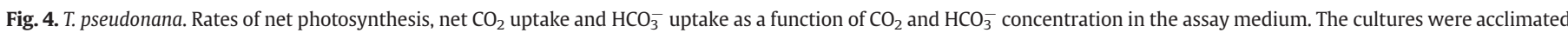
to $370 \mu \mathrm{atm}(\mathrm{a}, \mathrm{b})$ and $800 \mu \mathrm{atm}(\mathrm{c}, \mathrm{d})$ of $\mathrm{CO}_{2}$ for at least $3 \mathrm{~d}$. Michaelis-Menten fits were obtained from at least three individual measurements. 
Table 2

$K_{1 / 2}$ and $V_{\max }$ values for photosynthesis, net $\mathrm{CO}_{2}$ uptake, and $\mathrm{HCO}_{3}^{-}$uptake for E. zodiacus, S. costatum, T. nitzschioides and T. pseudonana acclimated to ambient and high $\mathrm{CO}_{2}$ concentrations.

\begin{tabular}{|c|c|c|c|c|c|c|c|}
\hline \multirow{3}{*}{$\frac{\mathrm{pCO}_{2}}{(\mu \mathrm{atm})}$} & \multicolumn{3}{|c|}{ Photosynthesis } & \multicolumn{2}{|c|}{ Net $\mathrm{CO}_{2}$ uptake } & \multicolumn{2}{|c|}{$\mathrm{HCO}_{3}^{-}$uptake } \\
\hline & $\overline{K_{1 / 2}}$ & $K_{1 / 2}$ & $V_{\max }$ & $\overline{K_{1 / 2}}$ & $V_{\max }$ & $\overline{K_{1 / 2}}$ & $V_{\max }$ \\
\hline & $\left(\mathrm{CO}_{2}\right)$ & $\overline{(\mathrm{DIC})}$ & & $\overline{\left(\mathrm{CO}_{2}\right)}$ & & $\left(\mathrm{HCO}_{3}^{-}\right)$ & \\
\hline \multicolumn{8}{|c|}{ E. zodiacus } \\
\hline 370 & $2.9 \pm 0.4$ & $323 \pm 53$ & $414 \pm 19$ & $2.6 \pm 0.5$ & $123 \pm 7$ & $140 \pm 40$ & $274 \pm 19$ \\
\hline 800 & $3.6 \pm 0.5$ & $411 \pm 63$ & $454 \pm 16$ & $6.6 \pm 1.4$ & $234 \pm 3$ & $325 \pm 101$ & $214 \pm 19$ \\
\hline \multicolumn{8}{|c|}{ S. costatum } \\
\hline 370 & $2.8 \pm 0.4$ & $265 \pm 53$ & $309 \pm 14$ & $2.8 \pm 0.4$ & $65 \pm 6$ & $113 \pm 22$ & $236 \pm 10$ \\
\hline 800 & $3.1 \pm 0.4$ & $441 \pm 74$ & $371 \pm 14$ & $6.0 \pm 0.9$ & $208 \pm 3$ & $383 \pm 94$ & $168 \pm 12$ \\
\hline \multicolumn{8}{|c|}{ T. nitzschioides } \\
\hline 370 & $1.9 \pm 0.6$ & $223 \pm 41$ & $342 \pm 23$ & $2.7 \pm 1.0$ & $195 \pm 4$ & $130 \pm 15$ & $149 \pm 6$ \\
\hline 800 & $2.7 \pm 0.6$ & $379 \pm 78$ & $364 \pm 23$ & $3.6 \pm 1.6$ & $200 \pm 3$ & $294 \pm 77$ & $164 \pm 12$ \\
\hline \multicolumn{8}{|c|}{ T. pseudonana } \\
\hline 370 & $3.4 \pm 0.8$ & $513 \pm 86$ & $484 \pm 30$ & $3.8 \pm 1.2$ & $253 \pm 4$ & $463 \pm 73$ & $228 \pm 11$ \\
\hline 800 & $4.0 \pm 0.9$ & $443 \pm 98$ & $470 \pm 28$ & $3.4 \pm 1.1$ & $262 \pm 4$ & $380 \pm 96$ & $212 \pm 15$ \\
\hline
\end{tabular}

Kinetic parameters were calculated from a Michaelis-Menten fit to the combined data Values for $K_{1 / 2}$ and $V_{\max }$ are given in $\mu \mathrm{mol} \mathrm{L} \mathrm{L}^{-1}$ and $\mu \mathrm{mol}(\mathrm{mg} \mathrm{Chl} a)^{-1} \mathrm{~h}^{-1}$, respectively. Values represent the means of triplicate incubations $( \pm S D)$.

The $K_{1 / 2}$ and $V_{\max }$ for net $\mathrm{CO}_{2}$ uptake remained constant in $T$. nitzschioides and $T$. pseudonana independent of the $\mathrm{pCO}_{2}$ level ( $t$-test, $p>0.05$ ) while both parameters increased with increasing $\mathrm{pCO}_{2}$ in E. zodiacus and S. costatum ( $t$-test, ${ }^{* * *} p<0.001$; Figs. $1-4$, Table 2 ). Among the investigated species, $T$. pseudonana displayed the highest $V_{\max }$ for net $\mathrm{CO}_{2}$ uptake. $K_{1 / 2}$ values for $\mathrm{HCO}_{3}^{-}$uptake strongly decreased in all investigated species with decreasing $\mathrm{pCO}_{2}\left(t\right.$-test, $\left.{ }^{*} p<0.05\right)$ with the exception of $T$. pseudonana, for which the affinities remained unaffected over the tested range of $\mathrm{pCO}_{2}$ ( $t$-test, $p>0.05$ ). In E. zodiacus and $S$. costatum, $V_{\max }$ of $\mathrm{HCO}_{3}^{-}$uptake increased with increasing $\mathrm{pCO}_{2}$ level ( $t$-test, $\left.{ }^{*} p<0.05\right)$, while $V_{\max }$ remained constant in $T$. nitzschioides and T. pseudonana ( $t$-test, $p>0.05$ ).

Using the uptake kinetics obtained in the assay, the contribution of $\mathrm{HCO}_{3}^{-}$uptake relative to carbon fixation was estimated (Fig. 5). At the ambient $\mathrm{pCO}_{2}$ level, E. zodiacus and S. costatum obtained the highest relative $\mathrm{HCO}_{3}^{-}$contribution with $\sim 80 \%$ while at elevated $\mathrm{pCO}_{2}$ both carbon sources contributed equally to net fixation. For T. nitzschioides and T. pseudonana, the contribution of $\mathrm{HCO}_{3}^{-}$to net fixation was $\sim 50 \%$ independent of the $\mathrm{pCO}_{2}$ in the acclimation.

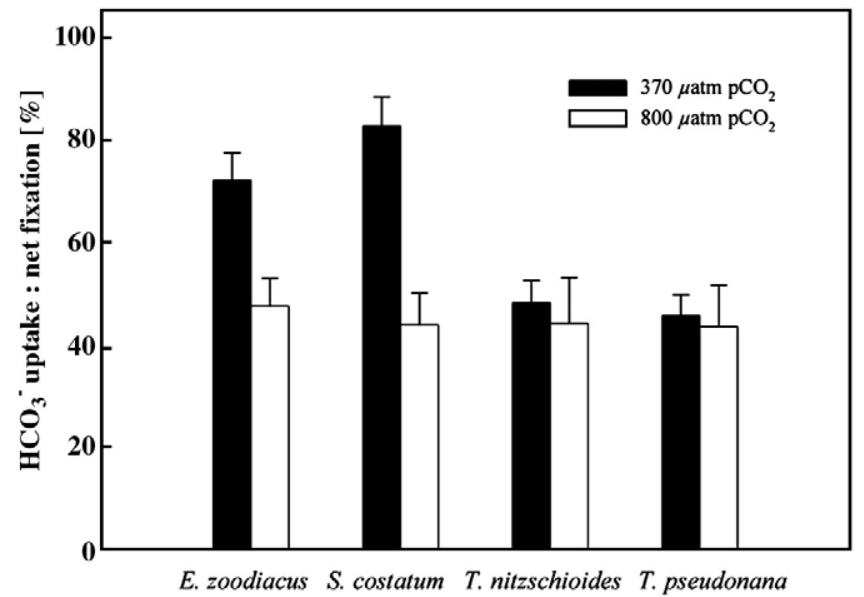

Fig. 5. Ratios of $\mathrm{HCO}_{3}^{-}$uptake:net photosynthesis of cells acclimated to $370 \mu$ atm and $800 \mu \mathrm{atm} \mathrm{CO}_{2}$. Ratios were based on the rates obtained at $\mathrm{Ci}$ concentrations of about 2 $\mathrm{mmol} \mathrm{L}^{-1}$ in at least three individual MIMS measurements.

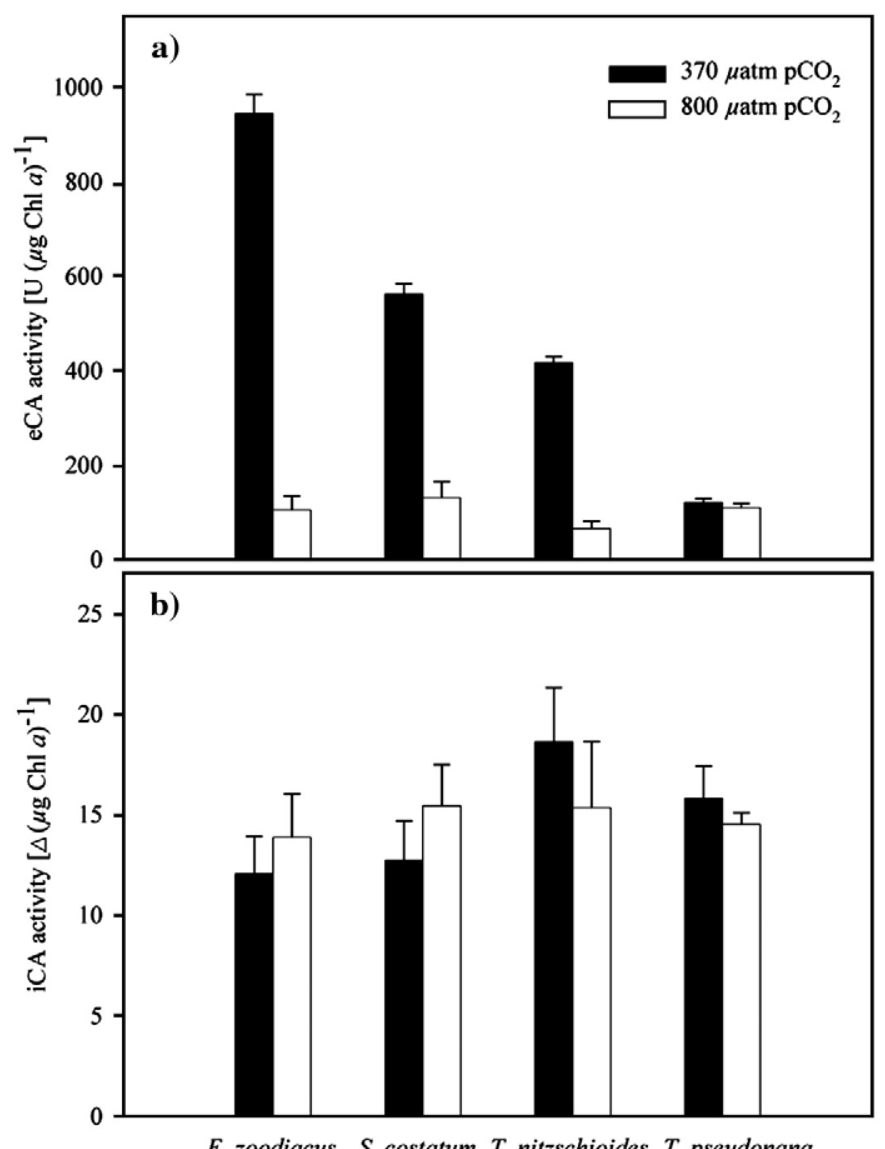

E. zoodiacus S. costatum T. nitzschioides $T$. pseudonana

Fig. 6. Activities of eCA (a) and iCA (b) activities from cells acclimated to $370 \mu$ atm and $800 \mu \mathrm{atm} \mathrm{CO}_{2}$. Values represent the means of triplicate incubations $( \pm \mathrm{SD})$.

\subsection{Extra- and intracellular CA activity}

With the exception of T. pseudonana, for which eCA activities were constant in all acclimations (t-test, $p>0.05$; Fig. 6a), eCA activities strongly increased with decreasing $\mathrm{pCO}_{2}$ in the other investigated species ( $t$-test, $\left.{ }^{* * *} p<0.001\right)$. In comparison, the highest eCA activities were exhibited by E. zodiacus with values of $\sim 940 \mathrm{U}(\mu \mathrm{g} \mathrm{Chl} a)^{-1}$ at ambient $\mathrm{CO}_{2}$ concentrations and lowest by T. pseudonana with values

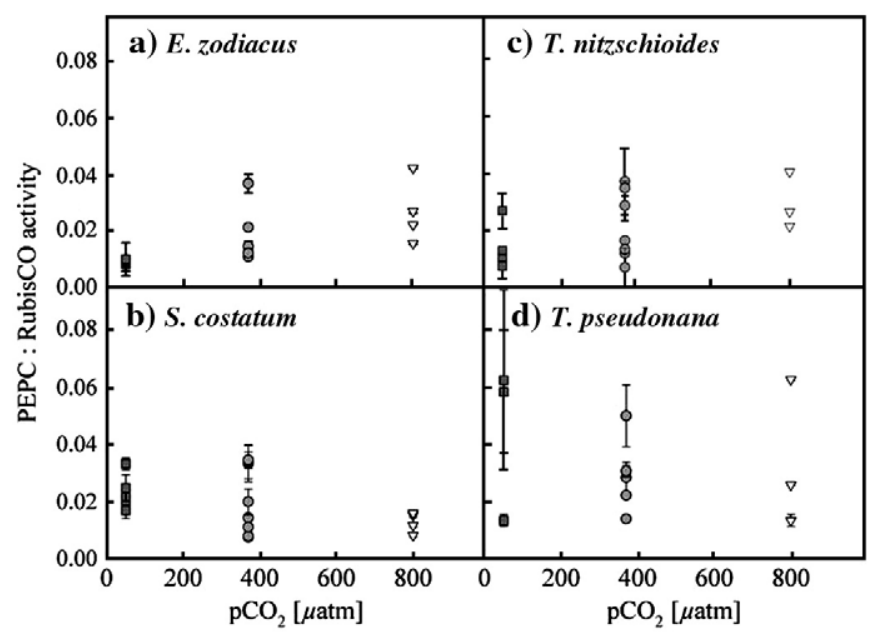

Fig. 7. The relative ratios of PEPC activity:RubisCO activity of cells acclimated to 50, 370 , and $800 \mu$ atm $\mathrm{CO}_{2}$. Error bars denote $\pm \operatorname{SD}(n \geq 3)$. 


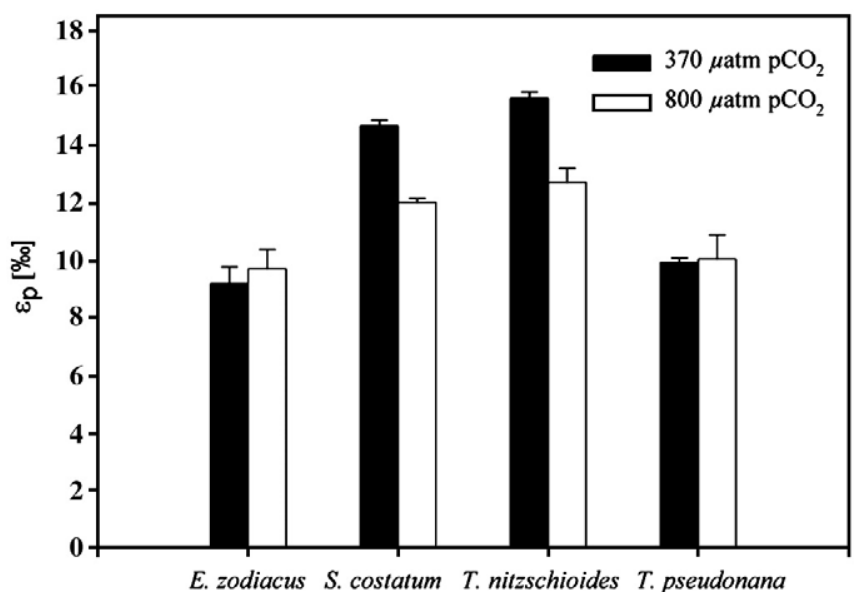

Fig. 8. Isotope fractionation $\left(\varepsilon_{\mathrm{p}}\right)$ from cells acclimated to $370 \mu \mathrm{atm}$ and $800 \mu \mathrm{atm} \mathrm{CO}_{2}$. Values for $\varepsilon_{\mathrm{p}}$ have been calculated from the ${ }^{13} \mathrm{C}_{\mathrm{CO} 2}$ and ${ }^{13} \mathrm{C}_{\mathrm{POC}}$ in the respective acclimations of each species. Error bars denote $\pm \operatorname{SD}(n=3)$.

of $\sim 120 \mathrm{U}(\mu \mathrm{g} \mathrm{Chl} a)^{-1}$. Intracellular CA activities were largely unaffected by the $\mathrm{pCO}_{2}$ in the acclimation ( $t$-test, $p>0.05$; Fig. $6 \mathrm{~b}$ ). In all investigated species, values for internal CA activities were similar.

\subsection{Activities of PEPC and RubisCO}

The activities of PEPC averaged generally less than 3\% of those observed for RubisCO. While the PEPC/RubisCO ratio decreased in E. zodiacus and T. nitzschioides with decreasing $\mathrm{PCO}_{2}$ in the acclimation (ANOVA, F-test, $* * * p<0.001$; Fig. 7a, c), for S. costatum variations in the ratio were significant between the $800 \mu \mathrm{atm}$ and the $370 \mu \mathrm{atm}$ $\mathrm{pCO}_{2}$ treatments (ANOVA, Bonferroni's multiple comparison test, $* * * p<0.001$ ), but not from $370 \mu$ atm down to $50 \mu$ atm $\mathrm{pCO}_{2}$ (ANOVA, Bonferroni's multiple comparison test, $p>0.05$; Fig. 7b). For T. pseudonana, the ratio remained constant independent of the $\mathrm{pCO}_{2}$ (ANOVA, F-test, $p>0.05$; Fig. 7d).

\subsection{Carbon isotope fractionation}

With the exception of $T$. nitzschioides and $S$. costatum ( $t$-test, *** $p<0.001$ ), carbon isotope fractionation was not affected by $\mathrm{pCO}_{2}$ ( $t$-test, $p>0.05$; Fig. 8). While S. costatum and T. nitzschioides obtained the highest fractionation with values up to $15.6 \%$, for E. zodiacus and T. pseudonana $\varepsilon_{\mathrm{p}}$ values were $\sim 9.5 \%$.

\section{Discussion}

In the present study, we investigated carbon acquisition and intracellular assimilation in three bloom-forming diatoms and T. pseudonana in response to changes in $\mathrm{CO}_{2}$ supply. By means of MIMS techniques in combination with ${ }^{14} \mathrm{C}$-based assays and analysis of ${ }^{13} \mathrm{C}$ fractionation, different components of the CCM were characterised in each species. $C_{\mathrm{i}}$ uptake kinetics and extracellular CA activities were highly regulated in the investigated bloom-forming species while T. pseudonana displayed a very efficient, but not regulated CCM in response to the tested $\mathrm{CO}_{2}$ range (Table 2, Figs. 1-4, 6a).

\subsection{Photosynthetic $\mathrm{O}_{2}$ evolution}

By comparing the $K_{1 / 2}\left(\mathrm{CO}_{2}\right)$ for photosynthesis with the $K_{\mathrm{M}}$ of the few investigated RubisCOs of diatoms ( 31-41 $\left.\mu \mathrm{mol} \mathrm{CO}_{2} \mathrm{~L}^{-1}\right)$, the presence and the efficiency of a CCM can be assessed (Badger et al., 1998). In this case, the term 'efficiency' relates to the ability of a cell to reach $C_{\mathrm{i}}$-saturation in relation to DIC availability. The $K_{1 / 2}\left(\mathrm{CO}_{2}\right)$ values for photosynthesis ranged between 1.9 and $4.0 \mu \mathrm{mol} \mathrm{CO} \mathrm{L}^{-1}$ in the investigated species (Table 2, Figs. 1-4) indicating the operation of highly efficient CCMs. As for other marine diatom species, our findings are consistent with previously published $K_{1 / 2}$ values for photosynthesis obtained by MIMS (Burkhardt et al., 2001; Rost et al., 2003; Trimborn et al., 2008) or by measurements of photosynthetic $\mathrm{O}_{2}$ evolution in response to varying $C_{\mathrm{i}}$ concentrations (Burns and Beardall, 1987; Colman and Rotatore, 1995).

Another indication for the operation of a CCM are changes in affinities as a function of the acclimation conditions. This up- and down-regulation in $K_{1 / 2}$ values for photosynthesis in response to $\mathrm{CO}_{2}$ supply has been observed in the two bloom-forming species $S$. costatum and T. nitzschioides, but not in E. zodiacus and T.pseudonana at the investigated $\mathrm{pCO}_{2}$ levels. In agreement to our study, Rost et al. (2003) demonstrated for a strain of $S$. costatum (an isolate from the North Sea) that $K_{1 / 2}$ values for photosynthesis were $\sim 250 \mu \mathrm{mol} \mathrm{DIC} \mathrm{L}{ }^{-1}$ and $500 \mu \mathrm{mol} \mathrm{DIC} \mathrm{L}^{-1}$ in cells acclimated to ambient and $1800 \mu \mathrm{atm} \mathrm{pCO}_{2}$, respectively. Using the same strain of T. pseudonana as in our study, Fielding et al. (1998) performed measurements of photosynthetic $\mathrm{O}_{2}$ evolution in cells acclimated to DIC concentrations ranging from 0.2 to $2.75 \mathrm{mmol} \mathrm{L}^{-1}$. From their results, low CCM regulation in T. pseudonana under ambient and high $\mathrm{pCO}_{2}$ can be deduced as $K_{1 / 2}$ values for photosynthetic $\mathrm{O}_{2}$ evolution were similar with $\sim 460$ and $\sim 480 \mu \mathrm{mol} \mathrm{DIC} \mathrm{L}^{-1}$ under the respective DIC concentrations of $2.06 \mathrm{mmol}$ and $2.18 \mathrm{mmol} \mathrm{DIC} \mathrm{L}^{-1}$ (see Table 1 ).

Overall, the generally low $K_{1 / 2}$ values for photosynthesis suggest that all investigated species possess highly efficient CCMs at the investigated $\mathrm{pCO}_{2}$ levels. With respect to the ability of a species to regulate its $\mathrm{CCM}$ in response to $\mathrm{CO}_{2}$, the acclimation of cells to ambient and high $\mathrm{pCO}_{2}$ levels revealed that the two bloom-forming species S. costatum and T. nitzschioides operate strongly regulated CCMs in contrast to T. pseudonana and E. zodiacus. However, to gain more information about the underlying mechanisms that determine the efficiency and the regulation of a CCM, the individual components of the CCM such as the carbon sources and their uptake kinetics, the extra- and intracellular CA activities as well as the intracellular assimilation pathway will be discussed in the following paragraphs.

\subsection{Carbon sources and uptake kinetics}

In agreement with previous studies on carbon acquisition in marine diatoms (e.g., Burns and Beardall, 1987; Colman and Rotatore, 1995; Rotatore et al., 1995; Korb et al., 1997), simultaneous uptake of $\mathrm{CO}_{2}$ and $\mathrm{HCO}_{3}^{-}$was observed in the investigated diatom species (Table 2, Figs. 1-4). In addition to the estimates of the $C_{\mathrm{i}}$ sources, $\mathrm{HCO}_{3}^{-}$and $\mathrm{CO}_{2}$ uptake kinetics were determined during steady-state photosynthesis using the equations of Badger et al. (1994). According to our results, the preference for carbon species and $C_{\mathrm{i}}$ uptake kinetics differed among the investigated diatom species.

The two bloom-forming species E. zodiacus and S. costatum were characterised by a strong preference for $\mathrm{HCO}_{3}^{-}$at ambient $\mathrm{pCO}_{2}$ while both species used $\mathrm{CO}_{2}$ and $\mathrm{HCO}_{3}^{-}$in equal quantities at high $\mathrm{pCO}_{2}$ (Fig. 5). Korb et al. (1997) demonstrated by means of ${ }^{14} \mathrm{C}$-disequilibrium technique that $S$. costatum was able to take up $\mathrm{HCO}_{3}^{-}$, but did not quantify the rate or its contribution to photosynthesis. As in the present study, Rost et al. (2003) obtained an increasing preference for $\mathrm{HCO}_{3}^{-}$with decreasing $\mathrm{CO}_{2}$ concentrations in another strain of $\mathrm{S}$. costatum. Such an up-regulation in $\mathrm{HCO}_{3}^{-}$transport, as was observed for the two bloomforming species E. zodiacus and S. costatum (Table 2), might be ascribed to both an increasing number of $\mathrm{HCO}_{3}^{-}$transporters and the induction of high affinity $\mathrm{HCO}_{3}^{-}$uptake systems under these conditions. In contrast to the species above, T. nitzschioides and T. pseudonana did not alter the relative contributions of $\mathrm{HCO}_{3}^{-}$or $\mathrm{CO}_{2}$ as a function of $\mathrm{CO}_{2}$ supply (Fig. 5). While the bloom-forming $T$. nitzschioides compensated for decreasing $\mathrm{CO}_{2}$ supply during acclimation by strongly increasing substrate affinities of the $\mathrm{HCO}_{3}^{-}$uptake system, $C_{\mathrm{i}}$ uptake kinetics of the non-bloom-forming T. pseudonana hardly responded to the tested $\mathrm{pCO}_{2}$ levels (Table 2). For T. nitzschioides, the increase in substrate affinity could be either due to 
posttranslational modifications (Sültemeyer et al., 1998) or to an increasing expression of a high affinity uptake system (e.g. Shibata et al., 2002). According to Elzenga et al. (2000), who applied the ${ }^{14} \mathrm{C}-$ disequilibrium technique, T. pseudonana solely relied on $\mathrm{HCO}_{3}^{-}$, which stands in contrast to our results. Despite differences in the approach taken between Elzenga et al. (2000) and the present study, a recent method comparison showed that MIMS and ${ }^{14} \mathrm{C}$-disequilibrium technique yield identical estimates for the $\mathrm{HCO}_{3}^{-}$contribution to net carbon fixation (Rost et al., 2007). The higher $\mathrm{HCO}_{3}^{-}$contribution for T. pseudonana obtained by Elzenga et al. (2000) may have been the result of the rather high rate constants $\left(\alpha_{1}\right.$ and $\left.\alpha_{2}\right)$ as well as the low $\mathrm{CO}_{2}$ equilibrium concentration for the $\mathrm{pH} 7.0$ spike used in their fit function.

According to our results, bloom-forming diatom species possess highly regulated $C_{i}$ uptake systems when exposed to ambient and high $\mathrm{pCO}_{2}$ levels while $C_{\mathrm{i}}$ uptake kinetics hardly responded in the nonbloom-forming T. pseudonana under these conditions. A high plasticity in the preference for $\mathrm{CO}_{2}$ or $\mathrm{HCO}_{3}^{-}$as well as the ability to regulate the affinities of $C_{\mathrm{i}}$ uptake systems has been reported previously for the group of diatoms, in particular for bloom-forming representatives (e.g. Burkhardt et al., 2001; Trimborn et al., 2008). Such high flexibility in the use of $C_{\mathrm{i}}$ sources appears to be exceptional, especially when compared to other taxa like dinoflagellates or cyanobacteria (Nimer et al., 1999; Leggat et al., 1999; Dason et al., 2004; Rost et al., 2006a; Price et al., 2007; Ratti et al., 2007).

\subsection{Carbonic anhydrase activity}

The enzyme carbonic anhydrase is considered to be an important component of the CCM (Sültemeyer, 1998; Badger, 2003; Moroney and Ynalvez, 2007) as it catalyses the conversion between $\mathrm{HCO}_{3}^{-}$and $\mathrm{CO}_{2}$. In agreement with previous investigations (Nimer et al., 1997; Burkhardt et al., 2001; Rost et al., 2003; Trimborn et al., 2008), externally located CA was found to be up-regulated with decreasing $\mathrm{CO}_{2}$ supply in all tested diatom species except for T. pseudonana (Fig. 6a). Highest eCA activities were found in the bloom-forming species with values up to $940 \mathrm{U}(\mu \mathrm{g}$ Chl $a)^{-1}$ for E. zodiacus while T. pseudonana displayed lowest eCA activities of $120 \mathrm{U}(\mu \mathrm{g} \mathrm{Chl} a)^{-1}$. These values correspond to an enhancement of the spontaneous $\mathrm{HCO}_{3}^{-} / \mathrm{CO}_{2}$ interconversion by $940 \%$ and $120 \%$ per $\mu \mathrm{g}$ Chl $a$. For T. pseudonana, the absence of significant eCA activities has also been verified using either the ${ }^{14} \mathrm{C}$-disequilibrium technique (Elzenga et al., 2000) or the potentiometric method (Nimer et al., 1997). Therefore, we conclude that eCA plays an important role in the carbon acquisition of bloom-forming diatom species while eCA activities are negligible in T. pseudonana.

It has been a common notion that eCA functions to increase the $\mathrm{CO}_{2}$ concentration in the boundary layer by converting $\mathrm{HCO}_{3}^{-}$to $\mathrm{CO}_{2}$ and herewith facilitate $\mathrm{CO}_{2}$ uptake (e.g. Badger and Price, 1994; Sültemeyer, 1998; Elzenga et al., 2000; Tortell et al., 2006). However, results from model calculations indicated that eCA activities may be insufficient to significantly enhance $\mathrm{CO}_{2}$ supply in marine microalgae with a cell radius of $10 \mu \mathrm{m}$ or less (Wolf-Gladrow and Riebesell, 1997). Furthermore, high eCA activities are often induced under elevated $\mathrm{pH}$, hence low $\mathrm{CO}_{2}$ equilibrium concentrations, and correlate with predominant uptake of $\mathrm{HCO}_{3}^{-}$(Burkhardt et al., 2001; Rost et al., 2003; Trimborn et al., 2008; Martin and Tortell, 2008). Based on these observations from laboratory and field experiments, Trimborn et al. (2008) proposed that eCA acts to convert effluxing $\mathrm{CO}_{2}$ to $\mathrm{HCO}_{3}^{-}$, which is subsequently taken up via the $\mathrm{HCO}_{3}^{-}$transporter. Such a $C_{\mathrm{i}}$ recycling mechanism would be most efficient when $\mathrm{CA}$-mediated conversion is localized to the periplasmic space, i.e. in close vicinity of the $\mathrm{HCO}_{3}^{-}$transporter. The results of the present study, i.e. high eCA activities in concert with a strong $\mathrm{HCO}_{3}^{-}$ preference in E. zodiacus and S. costatum (Figs. 5 and 6a), are consistent with previous findings and provide, even though the novel role of eCA yet needs to be rigorously tested, further support for such a $C_{\mathrm{i}}$ recycling mechanism to operate in a large number of diatoms.
The role of intracellular CA is also under debate and its function(s) possibly differs strongly depending on the location within the cell (Badger and Price, 1994; Sültemeyer, 1998; Badger, 2003; Moroney and Ynalvez, 2007). This is important to bear in mind because the in vivo approach applied in this study (Palmqvist et al., 1994) does not differentiate between the various iCA forms. Furthermore, the estimates of the iCA activities rely on the diffusive influx of doubly labelled $\mathrm{CO}_{2}$ and thus on membrane properties, intracellular $\mathrm{pH}$ and $\mathrm{CO}_{2}$ concentrations as well as cell size and shape. Consequently, $\Delta$ values have arbitrary units and a direct species comparison should be treated with caution. In the present study, all four diatom species contained iCA regardless of the growth condition (Fig. 6b). In contrast to Burkhardt et al. (2001) who found a gradual increase in iCA activity with decreasing $\mathrm{pCO}_{2}$ in the acclimation, results of our previous investigations (Fig. 6b) (Palmqvist et al., 1994; Rost et al., 2003; Trimborn et al., 2008) could not support this finding. Trimborn et al. (2008) suggested that cytosolic iCA may most likely be involved in a mechanism reducing the efflux from the cell. Consequently, species predominantly relying on $\mathrm{HCO}_{3}^{-}$would have low cytosolic iCA activities to prevent the $\mathrm{HCO}_{3}^{-}$taken up from being converted to $\mathrm{CO}_{2}$. In contrast, species predominantly taking up $\mathrm{CO}_{2}$ would have rather high cytosolic iCA activities to equilibrate $\mathrm{CO}_{2}$ quickly into $\mathrm{HCO}_{3}^{-}$and thus preventing it from leaking out of the cell. As shown in Fig. 6b, values for iCA activities were similar irrespective of the preferred carbon source (Fig. 5). Hence, the present data do not support the proposed $\mathrm{CO}_{2}$ trapping mechanism by Trimborn et al. (2008). However, considering the methodological uncertainties about absolute activities and location of iCA, other approaches have to be applied to clarify the role of iCA in carbon acquisition.

\subsection{The role of $\mathrm{C}_{4}$-like photosynthesis in marine diatoms}

Evidence for unicellular $\mathrm{C}_{4}$-like photosynthesis came from ${ }^{14} \mathrm{C}$ labelling experiments (Reinfelder et al., 2000; Morel et al., 2002) and experiments with a PEPC inhibitor for the marine diatom $T$. weissflogii (Reinfelder et al., 2004). Reinfelder et al. (2000) suggested that PEPC is the primary carboxylase in the cytoplasm that forms $\mathrm{C}_{4}$ compounds from PEP and $\mathrm{HCO}_{3}^{-}$. The $\mathrm{C}_{4}$ compound malate/oxaloacetate is then transported into the chloroplast and decarboxylated by phosphoenolpyruvate carboxykinase (PEPCK) in close proximity of RubisCO to support carbon fixation. Reinfelder et al. (2000) demonstrated that PEPC activity was up-regulated at low $\mathrm{CO}_{2}$ concentrations in $\mathrm{T}$. weissflogii and that the measured PEPC activities contributed up to 50\% to carbon fixation under zinc limitation. Even though the assay applied in their study does not exclude the anaplerotic role of PEPC, which is considered to be involved in the synthesis of amino-acid precursors (Descolas-Gros and Oriol, 1992), the observation that the ${ }^{14} \mathrm{C}$ labelled $\mathrm{C}_{4}$ compound malate was so rapidly formed in T. weissflogii (Reinfelder et al., 2000; Morel et al., 2002; McGinn and Morel, 2008) indicates photosynthetic $\mathrm{C}_{4}$ fixation rather than anaplerotic processes. However, recent studies (e.g. Johnston et al., 2001; Granum et al., 2005; Kroth et al., 2008) criticized the findings by Reinfelder and others and have also provided evidence of $\mathrm{C}_{3}-\mathrm{C}_{4}$ intermediate photosynthesis in $\mathrm{T}$. weissflogii (Roberts et al., 2007a,b).

In the current study, we used the same experimental ${ }^{14} \mathrm{C}$-based assay as Reinfelder et al. (2000). According to Cassar and Laws (2007), the latter protocol provides higher PEPC activities than the Descolas-Gros and Oriol (1992) methodology. Even though the obtained results from the applied assays provide information on the in vitro and not on the in vivo activities, it is emphasized here that observed changes in the enzyme activities can be taken as relative changes in response to changes in $\mathrm{pCO}_{2}$. In our experiments, the PEPC/RubisCO ratios indicate PEPC activities being generally lower than $3 \%$ relative to carbon fixation by RubisCO (Fig. 7). In comparison, similarly low values are typical for higher $C_{3}$ plants while much higher PEPC/RubisCO ratios (>20\%) are indicative for the operation of the $C_{4}$ pathway (Keeley, 1999). Moreover, 
the PEPC/ RubisCO ratio did not increase with decreasing $\mathrm{pCO}_{2}$ in any of the tested diatom species. Our low PEPC/RubisCO ratios are consistent with values obtained in laboratory experiments with $P$. tricornutum (Cassar and Laws, 2007) and in field studies with diatom-dominated phytoplankton assemblages (Tortell et al., 2006). The lack of significant PEPC activity in T. pseudonana (Fig. 7) is in agreement with the findings by Granum et al. (2005) and Roberts et al. (2007b). Granum et al. (2005) revealed the same levels of PEPC expression in T. pseudonana cells grown at 400 and $100 \mu \mathrm{atm} \mathrm{pCO}_{2}$ using qPCR. Roberts et al. (2007b) demonstrated that $T$. pseudonana exclusively relies on $C_{3}$ photosynthesis even under low $\mathrm{CO}_{2}$ concentrations either by performing ${ }^{14} \mathrm{C}$ short-term incubations as well as by measuring gene transcripts and protein abundances of $\mathrm{C}_{4}$-metabolic enzymes. McGinn and Morel (2008) postulated the prevalence of a $\mathrm{C}_{4}$-like pathway in $T$. pseudonana and P. tricornutum based on analysis of gene transcripts of PEPC and PEPCK and inhibitor studies of these enzymes. They observed a 3-fold upregulation of PEPC transcripts in T. pseudonana under low $\mathrm{pCO}_{2}$ acclimation, but did not analyse total protein content for this enzyme. Please note that transcript levels are often not a reliable proxy for the amounts of corresponding functional enzymes (Gibon et al., 2004). Moreover, the localization of malate and/or oxaloacetate transporters to plastid membranes is not supported in T. pseudonana and P. tricornutum (Kroth et al., 2008), thus calling into question the importance of PEPC in $\mathrm{C}_{4}$ fixation. Overall, the results of the present study suggest that PEPC activity does not significantly contribute to photosynthesis in the investigated species even under low $\mathrm{CO}_{2}$ supply. In agreement with previous investigations, the combined data suggest rather an anaplerotic role of PEPC. Future experiments should explore whether or not other enzymes involved in $\mathrm{C}_{4}$ photosynthesis fulfil the role that has previously been attributed to PEPC (Reinfelder et al., 2000, 2004).

Isotopic composition of autotrophs reflects changes in carbon fluxes as well as carbon assimilation pathways. Even though it is not possible to distinguish between $\mathrm{C}_{4}$ photosynthesis and a classical CCM only on the basis of $\mathrm{C}$ isotope fractionation, the ${ }^{13} \mathrm{C}$ signal can provide some information about photosynthetic pathways. Opposed to the classical $C_{3}$ photosynthesis driven by RubisCO, the $\mathrm{C}_{4}$-pathway is known to deplete the apparent fractionation. Most of this is the result of PEPC, which has a much lower intrinsic fractionation than RubisCO and uses $\mathrm{HCO}_{3}^{-}$as its carbon source. The intrinsic fractionation factor of PEPC with respect to its substrate $\mathrm{HCO}_{3}^{-}$is very small ( $2.9 \%$, O'Leary et al., 1992) and when expressed relative to $\mathrm{CO}_{2}$ leads to fractionation values of $-4.7 \%$. In contrast, the intrinsic fractionation by RubisCO is very high with values $\sim 29 \%$ (Raven and Johnston, 1991). If a large part of $C_{\mathrm{i}}$ was assimilated via PEPC prior to the fixation by RubisCO, this would lead to $\varepsilon_{\mathrm{p}}$ values be even negative. In our four diatoms, $\varepsilon_{\mathrm{p}}$ values ranged between $9 \%$ and $16 \%$ (Fig. 8). These $\varepsilon_{\mathrm{p}}$ values are in agreement with previous studies investigating fractionation in diatoms (Burkhardt et al., 1999; Cassar and Laws, 2007). We conclude that the observed $\varepsilon_{\mathrm{p}}$ values and the variation in response to the $\mathrm{CO}_{2}$ supply can easily be explained by the operation of a classical CCM in the investigated species without invoking $\mathrm{C}_{4}$ photosynthesis (e.g., Raven and Johnston, 1991; Rost et al., 2002; Trimborn et al., 2008).

According to Reinfelder et al. $(2000,2004)$ the operation of a $\mathrm{C}_{4}$-like photosynthetic pathway provides a mean to significantly enhance the photosynthetic capacity under low $\mathrm{CO}_{2}$ concentrations. However, when species assumed operating $C_{3}$ and $C_{4}$ metabolism are compared, we cannot observe the suggested advantage for the latter pathway. T. pseudonana, which appears to operate $C_{3}$ metabolism (Granum et al., 2005; Roberts et al., 2007a,b; present study), photosynthesizes as efficiently as T. weissflogii (Fielding et al., 1998; Burkhardt et al., 2001; S. Trimborn, unpublished data), for which $\mathrm{C}_{4}$ metabolism has been postulated (Reinfelder et al., 2000, 2004; Morel et al., 2002). This is indicated by the similarly low $K_{1 / 2}\left(\mathrm{CO}_{2}\right)$ for photosynthesis under low $\mathrm{CO}_{2}$ supply ( $150 \mu \mathrm{atm} \mathrm{pCO}_{2}$ ) being $\sim 1.5 \mu \mathrm{mol} \mathrm{L}{ }^{-1} \mathrm{CO}_{2}$ (Fielding et al., 1998; Burkhardt et al., 2001; S. Trimborn, unpublished data). Hence, even if the $C_{4}$ pathway plays a primary role in photosynthesis in some species, it appears to provide no competitive advantage over diatoms operating classical CCMs.

\subsection{Ecological implications and conclusions}

It has been proposed that the dominance of species during bloom situations may depend on their ability to operate an efficient and regulated CCM (Rost et al., 2003; Trimborn et al., 2008). Therefore, one may assume that bloom-forming species possess most efficient and strongly regulated CCMs that allow to maintain high growth rates even under low $\mathrm{CO}_{2}$ availability (e.g. Hobson, 1988; Rost et al., 2003) while non-bloom-forming species may not depend on such high growth rates and consequently $C_{\mathrm{i}}$ uptake rates. In the current study, the comparison of bloom-forming and non-bloom-forming diatoms revealed that all tested species had highly efficient CCMs (Table 2). In comparison with T. pseudonana and E. zodiacus, the two bloom-forming species T. nitzschioides and $S$. costatum showed strongly regulated CCMs (Table 2). Even though $K_{1 / 2}$ values for photosynthesis did not change significantly in $E$. zodiacus, significant changes in the $C_{\mathrm{i}}$ uptake systems and eCA activities were found when this species was acclimated to ambient and high $\mathrm{pCO}_{2}$ levels, indicating strong regulation capacities of individual components of its CCM (Figs. 1-6, Table 2). It should be pointed out that significantly lower $K_{1 / 2}$ values for photosynthesis in T. pseudonana were obtained when exposed to even lower $\mathrm{pCO}_{2}$ levels than the ones applied in our study (Fielding et al., 1998). This is consistent to additional data for $T$. pseudonana where $C_{\mathrm{i}}$ flux measurements revealed $K_{1 / 2}$ values for photosynthesis as low as $\sim 120 \mu \mathrm{mol}$ DIC $\mathrm{L}^{-1}$ for cells having been acclimated to $150 \mu \mathrm{atm} \mathrm{pCO}_{2}$ (S. Trimborn, unpublished data). Furthermore, up-regulation of the CCM in response to low $\mathrm{pCO}_{2}$ levels was also observed for non-bloomforming species such as T. weissflogii, Nitzschia navis-varingica, and Stellarima stellaris (Burkhardt et al., 2001; Trimborn et al., 2008). Hence, the ability to operate an efficient and regulated CCM applies to bloomforming as well as to non-bloom-forming diatoms. Furthermore, considering that the bloom-forming coccolithophore Emiliania huxleyi operates a rather inefficient CCM, but yet regulated CCM in response to changes in $\mathrm{CO}_{2}$ (Rost et al., 2003), it can be concluded that an efficient $\mathrm{CCM}$ is not a prerequisite for bloom-forming species.

Taking into account that all diatom species examined so far mainly thrive in coastal areas, reasons for the observed high degree in CCM regulation of the investigated diatoms might be partially due to their occurrence in coastal areas that display regular and large changes in $\mathrm{CO}_{2}$ levels (Hansen, 2002; Hinga, 2002) as well as highly variable light conditions (Macintyre et al., 2000). Oceanic species, on the other hand, might exhibit less regulatory CCM capacities, but more studies are required to ultimately answer these questions. Future studies should also focus on the aspect of resource limitation in combination with $\mathrm{CO}_{2}$ effects as species might respond differently under these conditions.

In view of the ongoing acidification of the oceans (Wolf-Gladrow et al., 1999; Orr et al., 2005; IPCC, 2007), the expected increase in aquatic $\mathrm{pCO}_{2}$ may cause a down-regulation of the CCM capacity of diatoms (Figs. 1-4, 6, Table 2). This may result from an increasing diffusive $\mathrm{CO}_{2}$ uptake and/or reduced energetic costs of the CCM. The latter can be ascribed to a decrease in leakage owing to a smaller outward $\mathrm{CO}_{2}$ gradient under elevated $\mathrm{pCO}_{2}$ (e.g. Raven and Lucas, 1985; Rost et al., 2006a,b). As a consequence, diatoms may optimize their resource allocation and thus have more energy available for carbon fixation.

Considering the low $K_{1 / 2}\left(\mathrm{CO}_{2}\right)$ values for photosynthesis in the present and other studies focusing on marine diatoms (e.g. Burkhardt et al., 2001; Rost et al., 2003; Trimborn et al., 2008, present study), photosynthetic carbon fixation rates are close to saturation ( 80-95\%) in most diatom species under the projected high $\mathrm{CO}_{2}$ levels. Large diatoms such as $S$. stellaris may benefit to a larger extent from the projected increase in $\mathrm{CO}_{2}$ because of their lower affinities $\left(\mathrm{K}_{1 / 2}\left(\mathrm{CO}_{2}\right)\right.$ of $7.4 \mu \mathrm{mol} \mathrm{CO} \mathrm{L}^{-1}$ at high $\mathrm{pCO}_{2}$, Trimborn et al., 2008). It should be noted, however, that the observed $K_{1 / 2}$ values for photosynthesis were 
obtained under a constant $\mathrm{pH}$ of 8.0. In the assays, the ratio of $\mathrm{CO}_{2}$ to DIC therefore remains constant while in natural seawater an increase in $\mathrm{CO}_{2}$ is associated with decreasing $\mathrm{pH}$ and corresponding changes in the $\mathrm{CO}_{2}$ to DIC ratio. Nevertheless, incubations in unbuffered waters have also yielded higher photosynthetic carbon fixation rates under elevated $\mathrm{pCO}_{2}$ for instance in laboratory experiments with $S$. costatum (Burkhardt and Riebesell, 1997). The projected $\mathrm{CO}_{2} / \mathrm{pH}$-related changes in seawater carbonate chemistry are likely to induce a species shift within the diverse group of diatoms, which may have consequences for the operation of the biological pump and thus for oceanic feedbacks to rising atmospheric $\mathrm{CO}_{2}$.

\section{References}

Armbrust, E.V., Berges, J.A., Bowler, C., Green, B.R., Martinez, D., Putnam, N.H., Zhou, S Allen, A.E., Apt, K.E., Bechner, M., Brzezinski, M.A., Chaal, B.K., Chiovetti, A., Davids, A.K., Demarest, M.S., Detter, J.D., Glavina, T., Goodstein, D., Hadi, M.Z., Hellsten, U., Hildebrand, M., Jenkins, B.D., Jurka, J., Kapitonov, V.V., Kröger, N., Lau, W.W.Y., Lane, T.D., Larimer, F.W., Lippmeier, J.C., Lucas, S., Medina, M., Montsant, A., Obornik, M., Parker, M.S., Palenik, B., Pazour, G.J., Richardson, P.M., Rynearson, T.A., Saito, M.A. Schwartz, D.C., Thamatrakoln, K., Valentin, K., Vardi, A., Wilkerson, F.P., Rokhsar, D.S. 2004. The genome of the diatom Thalassiosira pseudonana: ecology, evolution and metabolism. Science 306, 79-86.

Asmus, R., 1982. Field measurements on seasonal variation of the activity of primary producers on a sandy tidal flat in the northern Wadden Sea. Neth. J. Sea Res. 16, 389-402.

Badger, M.R., 2003. The role of carbonic anhydrases in photosynthetic $\mathrm{CO}_{2}$ concentrating mechanisms. Photosynth. Res. 77, 83-94.

Badger, M.R., Price, G.D., 1989. Carbonic anhydrase activity associated with the cyanobacterium Synechococcus PCC7942. Plant Physiol. 89, 51-60.

Badger, M.R., Price, G.D., 1994. The role of carbonic anhydrase in photosynthesis. Annu. Rev. Plant Physiol. Plant Mol. Biol. 45, 369-392.

Badger, M.R., Palmqvist, K., Yu, J.-W., 1994. Measurement of $\mathrm{CO}_{2}$ and $\mathrm{HCO}_{3}^{-}$fluxes in cyanobacteria and microalgae during steady-state photosynthesis. Physiol. Plant. 90, 529-536

Badger, M.R., Andrews, T.J., Whitney, S.M., Ludwig, M., Yellowlees, D.C., Leggat, W., Price, G.D. 1998. The diversity and coevolution of RubisCO, plastids, pyrenoids, and chloroplastbased $\mathrm{CO}_{2}$-concentrating mechanisms in algae. Can. J. Bot. 76, 1052-1071.

Brewer, P.G., Bradshow, A.L., Williams, R.T., 1986. Measurement of total carbon dioxide and alkalinity in the North Atlantic Ocean in 1981. In: Trabalka, J.R., Reichle, D.E. (Eds.), The Changing Carbon Cycle - a Global Analysis. Springer, New York, pp. 358-381.

Buesseler, K.O., 1998. The decoupling of production and particulate export in the surface ocean. Glob. Biogeochem. Cycles 12, 297-310.

Burkhardt, S., Riebesell, U., 1997. $\mathrm{CO}_{2}$ availability affects elemental composition (C:N:P) of the marine diatom Skeletonema costatum. Mar. Ecol. Prog. Ser. 155, 67-76.

Burkhardt, S., Riebesell, U., Zondervan, I., 1999. Stable carbon isotope fractionation by marine phytoplankton in response to daylength, growth rate, and $\mathrm{CO}_{2}$ availability. Mar. Ecol. Prog. Ser. 184, 31-41.

Burkhardt, S., Amoroso, G., Riebesell, U., Sültemeyer, D., 2001. $\mathrm{CO}_{2}$ and $\mathrm{HCO}_{3}^{-}$uptake in marine diatoms acclimated to different $\mathrm{CO}_{2}$ concentrations. Limnol. Oceanogr. 46, 1378-1391.

Burns, B.D., Beardall, J., 1987. Utilization of inorganic carbon acquisition by marine microalgae. J. Exp. Mar. Biol. Ecol. 107, 75-86.

Cassar, N., Laws, E.A., 2007. Potential contribution of ß-carboxylases to photosynthetic carbon isotope fractionation in a marine diatom. Phycologia 46, 307-314.

Colman, B., Rotatore, C., 1995. Photosynthetic inorganic carbon uptake and accumulation in two marine diatoms. Plant Cell Environ. 18, 919-924.

Colman, B., Huertas, I.E., Bhatti, S., Dason, J.S., 2002. The diversity of inorganic carbon acquisition mechanisms in eukaryotic microalgae. Funct. Plant Biol. 29, 261-270.

Dason, J.S., Huertas, I.E., Colman, B., 2004. Source of inorganic carbon for photosynthesis in two marine dinoflagellates. J. Phycol. 40, 285-292.

Descolas-Gros, C., Oriol, L., 1992. Variations in carboxylase activity in marine phytoplankton cultures. ß-carboxylation in carbon flux studies. Mar. Ecol. Prog. Ser. 85, 163-169.

Dickson, A.G., Millero, F.J., 1987. A comparison of the equilibrium constants for the dissociation of carbonic acid in seawater media. Deep-Sea Res. 34, 1733-1743.

Edwards, M., Licandro, P., John, A.W.G., Johns, D.G., 2005. Ecological status report: results from the CPR survey 2003/2004. SAHFOS Technical Report, vol. 2, pp. 1-6.

Elzenga, J.T.M., Prins, H.B.A., Stefels, J., 2000. The role of extracellular carbonic anhydrase activity in inorganic carbon utilization of Phaeocystis globosa (Prymnesiophyceae): a comparison with other marine algae using the isotope disequilibrium technique. Limnol. Oceanogr. 45, 372-380.

Falkowski, P.G., Katz, M.E., Knoll, A.H., Quigg, A., Raven, J.A., Schofield, O., Taylor, F.J.R., 2004. The evolution of modern eukaryotic phytoplankton. Science 305, 354-360.

Fielding, A.S., Turpin, D.H., Guy, R.D., Calvert, S.E., Crawford, D.W., Harrison, P.J., 1998 Influence of the carbon concentrating mechanism on carbon isotope discrimination by the marine diatom Thalassiosira pseudonana. Can. J. Bot. 76, 1098-1103.

Freeman, K.H., Hayes, J.M., 1992. Fractionation of carbon isotopes by phytoplankton and estimates of ancient $\mathrm{CO}_{2}$ levels. Glob. Biogeochem. Cycles 6, 185-198.

Gibon, Y., Blaesing, O.E., Hannemann, J., Carillo, P., Höhne, M., Hendriks, J.H.M., Palacios, N., Cross, J., Selbig, J., Stitt, M., 2004. A robot-based platform to measure multiple enzyme activities in Arabidopsis using a set of cycling assays: comparison of changes in enzyme activities and transcript levels during diurnal cycles and in prolonged darkness. Plant Cell 16, 3304-3325.
Giordano, M., Beardall, J., Raven, J.A., 2005. $\mathrm{CO}_{2}$ concentrating mechanisms in algae: mechanisms, environmental modulation, and evolution. Annu. Rev. Plant Biol. 56, 99-131.

Gran, G., 1952. Determinations of the equivalence point in potentiometric titrations of seawater with hydrochloric acid. Oceanol. Acta 5, 209-218.

Granum, E., Raven, J.A., Leegood, R.C., 2005. How do marine diatoms fix 10 billion tonnes of inorganic carbon per year? Can. J. Bot. 83, 898-908.

Guillard, R.R.L., Ryther, J.H., 1962. Studies of marine planktonic diatoms. Can. J. Microbiol. 8, 229-239.

Hansen, P.J., 2002. Effect of high pH on the growth and survival of marine phytoplankton: implications for species succession. Aquat. Microb. Ecol. 28, 279-288.

Hinga, K.R., 2002. Effects of pH on coastal marine phytoplankton. Mar. Ecol. Prog. Ser. 238, 281-300.

Hobson, L.A., 1988. Paradox of the phytoplankton - an overview. Biol. Oceanogr. 6, 493-504.

Hobson, L.A., McQuoid, M.R., 1997. Temporal variations among planktonic diatom assemblages in a turbulent environment of the southern Strait of Georgia, British Columbia, Canada. Mar. Ecol. Prog. Ser. 150, 263-274.

IPCC (Intergovernmental panel on climate change), 2007. Working Group 1 Report, The Physical Science Basis. http://ipcc-wg1.ucar.edu/wg1/wg1-report.html.

Johnston, A.M., Raven, J.A., Beardall, J., Leegood, R.C., 2001. Photosynthesis in a marine diatom. Nature 412, 40-41.

Keeley, J.E., 1999. Photosynthetic pathway diversity in a seasonal pool community. Funct. Ecol. 13, 106-118

Korb, R.E., Saville, P.J., Johnston, A.M., Raven, J.A., 1997. Sources for inorganic carbon for photosynthesis by three marine species of marine diatom. J. Phycol. 33, 433-444.

Kroth, P.G., Chiovitti, A., Gruber, A., Martin-Jezequel, V., Mock, T., Parker, M. Schnitzler, Stanley, M.S., Kaplan, A., Caron, L., Weber, T., Maheswari, U., Armbrust, E.V., Bowler, C., 2008. A model for carbohydrate metabolism in the diatom Phaeodactylum tricornutum deduced from comparative whole genome analysis. PLoS ONE 3 (1), e1426. doi: 10.1371/ journal.pone.0001426.

Leggat, W., Badger, M.R., Yellowlees, D., 1999. Evidence for an inorganic carbonconcentrating mechanism in the symbiotic dinoflagellate Symbiodinium sp. Plant Physiol. 121, 1247-1255

Lewis, E., Wallace, D.W.R., 1998. Program developed for $\mathrm{CO}_{2}$ system calculations. ORNL/ CDIAC-105. Carbon Dioxide Information Analysis Center. Oak Ridge National Laboratory, U.S. Department of Energy.

MacIntyre, H.L., Geider, R.J., 1996. Regulation of RubisCO activity and its potential effect on photosynthesis during mixing in a turbid estuary. Mar. Ecol. Prog. Ser. 144, 247-264.

MacIntyre, H.L., Sharkey, T.D., Geider, R.J., 1997. Activation and deactivation of ribulose1,5-bisphosphate carboxylase/oxygenase (RubisCO) in three marine microalgae. Photosynth. Res. 51, 93-106.

MacIntyre, H.L., Kana, T.M., Geider, J.R., 2000. The effect of water motion on short-term rates of photosynthesis by marine phytoplankton. Trends Plant Sci. 5, 12-16.

Marshall, H.G., 1976. Phytoplankton distribution along the Eastern Coast of the USA. Part 1. Phytoplankton composition. Mar. Biol. 38, 81-89.

Marshall, H.G., 1978. Phytoplankton distribution along the Eastern Coast of the USA. Part 2. Seasonal assemblages north of Cape Hatteras, North Carolina. Mar. Biol. 45, 203-208.

Martin, C.L. Tortell, P.D. 2008. Bicarbonate transport and extracellular carbonic anhydrase in marine diatoms. Physiol. Plant 133, 106-116. doi: 10.1111/j.13993054.2008.01054.x

McGinn, P.J., Morel, F.M.M., 2008. Expression and inhibition of the carboxylating and decarboxylating enzymes in the photosynthetic $C_{4}$ pathway of marine diatoms. Plant Physiol. 146, 300-309.

Mehrbach, C., Culberson, C., Hawley, J., Pytkovicz, R., 1973. Measurement of the apparent dissociation constants of carbonic acid in seawater at atmospheric pressure. Limnol. Oceanogr. 18, 897-907.

Mills, D.K., Wilkinson, M., 1986. Photosynthesis and light in estuarine benthic microalgae. Bot. Mar. 29, 125-129.

Mitchell, C., Beardall, J., 1996. Inorganic carbon uptake by an Antarctic sea-ice diatom, Nitzschia frigida. Polar Biol. 16, 95-99.

Mook, W.G., 1986. ${ }^{13} \mathrm{C}$ in atmospheric $\mathrm{CO}_{2}$. Neth. J. Sea Res. 20, 211-223.

Morel, F.M.M., Cox, E.H., Kraepiel, A.M.L., Lane, T.W., Milligan, A.J., Schaperdoth, I., Reinfelder, J.A., Tortell, P.D., 2002. Acquisition of inorganic carbon by the marine diatom Thalassiosira weissflogii. Funct. Plant Biol. 29, 301-308.

Moroney, J.V., Ynalvez, R.A., 2007. Proposed carbon dioxide concentrating mechanism in Chlamydomonas reinhardtii. Eukaryotic Cell 6 (8), 1251-1259. doi: 10.1128/ EC.00064-07.

Nelson, D.M., Tréguer, P., Brzezinski, M.A., Leynaert, A., Quéginer, B., 1995. Production and dissolution of biogenic silica in the ocean: revised global estimates, comparison with regional data and relationship to biogenic sedimentation. Glob. Biogeochem. Cycles 9, 359-372.

Nimer, N.A., Iglesias-Rodriguez, M.D., Merrett, M.J., 1997. Bicarbonate utilization by marine phytoplankton species. J. Phycol. 33, 625-631.

Nimer, N.A., Brownlee, C., Merrett, M.J., 1999. Extracellular carbonic anhydrase facilitates carbon dioxide availability for photosynthesis in the marine dinoflagellate Prorocentrum micans. Plant Physiol. 120, 105-111.

O'Leary, M.H., Madhavan, S., Paneth, P., 1992. Physical and chemical basis of carbon isotope fractionation in plants. Plant Cell Environ. 15, 1099-1104.

Orr, J.C., Fabry, V.J., Aumont, O., Bopp, L., Doney, S.C., Feely, R.A., Gnanadesikan, A., Gruber, N., Ishida, A., Joos, F., Key, R.M., Lindsay, K., Maier-Reimer, E., Matear, R., Monfray, P., Mouchet, A., Najjar, R.G., Plattner, G.-K., Rodgers, K.B., Sabine, C.L., Sarmiento, J.L., Schlitzer, R., Slater, R.D., Totterdell, I.J., Weirig, M.-F., Yamanaka, Y., Yool, A., 2005. Anthropogenic ocean acidification over the twenty-first century and its impact on calcifying organisms. Nature 437, 681-686. 
Palmqvist, K., Yu, J.-W., Badger, M.R., 1994. Carbonic anhydrase activity and inorganic carbon fluxes in low- and high-Ci cells of Chlamydomonas reinhardtii and Scenedesmus obliquus. Physiol. Plant. 90, 537-547.

Price, G.D., Badger, M.R., Woodger, F.J., Long, B.M., 2007. Advances in understanding the cyanobacterial $\mathrm{CO}_{2}$-concentrating mechanism $(\mathrm{CCM})$ : functional components, $\mathrm{Ci}$ transporters, diversity, genetic regulation and prospects for engineering into plants. J. Exp. Bot 59, 1441-1461. doi: 10.1093/jxb/erm112.

Ratti, S., Giordano, M., Morse, D., 2007. $\mathrm{CO}_{2}$-concentrating mechanisms of the potentially toxic dinoflagellate Protoceratium reticulatum (Dinophyceae, Gonyaulacales). J. Phycol. 43, 693-701.

Raven, J.A., 1997. The vacuole: a cost-benefit analysis. Adv. Bot. Res. 25, 59-86.

Raven, J.A., Lucas, W.J., 1985. Energy costs of carbon acquisition. In: Lucas, W.J., Berry, J.A (Eds.), Inorganic Carbon Uptake by Aquatic Photosynthetic Organisms. American Society of Plant Physiologists, Rockville, MD, pp. 305-324.

Raven, J.A., Johnston, A.M., 1991. Mechanisms of inorganic carbon acquisition in marine phytoplankton and their implications for the use of other resources. Limnol. Oceanogr. 36, 1701-1714.

Reinfelder, J.R., Kraepiel, A.M.L., Morel, F.M.M., 2000. Unicellular $\mathrm{C}_{4}$ photosynthesis in a marine diatom. Nature 407, 996-999.

Reinfelder, J.R., Milligan, A.J., Morel, F.M.M., 2004. The role of the $\mathrm{C}_{4}$ pathway in carbon accumulation and fixation in a marine diatom. Plant Physiol. 135, 2106-2111.

Roberts, K., Granum, E., Leegood, R.C., Raven, J.A., 2007a. Carbon acquisition by diatoms. Photosynth. Res 93, 79-88. doi: 10.1007/s11120-007-9172-2.

Roberts, K., Granum, E., Leegood, R.C., Raven, J.A., 2007b. C3 and C4 pathways of photosynthetic carbon assimilation in marine diatoms are under genetic, not environmental, control. Plant Physiol. doi: 10.1104/pp.107.102616.

Rost, B., Zondervan, I., Riebesell, U., 2002. Light-dependant carbon isotope fractionation in the coccolithophorid Emiliania huxleyi. Limnol. Oceanogr. 47, 120-128.

Rost, B., Riebesell, U., Burkhardt, S., Sültemeyer, D., 2003. Carbon acquisition of bloomforming marine phytoplankton. Limnol. Oceanogr. 48, 55-67.

Rost, B., Richter, K.-U., Riebesell, U., Hansen, P.J., 2006a. Inorganic carbon acquisition in red tide dinoflagellates. Plant Cell Environ. 29, 810-822.

Rost, B., Riebesell, U., Sültemeyer, D., 2006b. Carbon acquisition of marine phytoplankton. Effect of photoperiod length. Limnol. Oceanogr. 51, 12-20.

Rost, B., Kranz, S., Richter, K.-U., Tortell, P., 2007. Isotope disequilibrium and mass spectrometric studies of inorganic carbon acquisition by phytoplankton. Limnol. Oceanogr. Methods 5, 328-337.
Rotatore, C., Colman, B., Kuzma, M., 1995. The active uptake of carbon dioxide by the marine diatoms Phaeodactylum tricornutum and Cyclotella sp. Plant Cell Environ. 18, 913-918.

Shibata, M., Ohkawa, H., Katoh, H., Shimoyama, M., Ogawa, T., 2002. Two $\mathrm{CO}_{2}$ uptake systems in cyanobacteria: four systems for inorganic carbon acquisition in Synechocystis sp. strain PCC6803. Funct. Plant Biol. 29, 123-129.

Silverman, D.N., 1982. Carbonic anhydrase. Oxygen-18 exchange catalyzed by an enzyme with rate contributing proton-transfer steps. Methods Enzymol. 87, $732-752$.

Smetacek, V., 1999. Diatoms and the ocean carbon cycle. Protist 150, 25-32.

Sültemeyer, D., 1998. Carbonic anhydrase in eukaryotic algae: characterization, regulation, and possible function during photosynthesis. Can. J. Bot. 76, 962-972.

Sültemeyer, D., Klughammer, B., Badger, M.R., Price, G.D., 1998. Fast induction of high affinity $\mathrm{HCO}_{3}^{-}$transport in cyanobacteria. Plant Physiol. 116, 183-192.

Tortell, P.D., Martin, C.L., Corkum, M.E., 2006. Inorganic carbon uptake and intracellular assimilation by subarctic Pacific assemblages. Limnol. Oceanogr. 51, 2102-2110.

Tortell, P.D., Payne, C.D., Li, Y., Trimborn, S., Rost, B., Smith, W.O., Riesselman, C., Dunbar R.B., Sedwick, P., DiTullio, G.R., 2008. The $\mathrm{CO}_{2}$ sensitivity of Southern Ocean phytoplankton. Geophys. Res. Lett 35, L04605. doi: 10.1029/2007GL032583.

Trimborn, S., Lundholm, N., Thoms, S., Richter, K.-U., Krock, B., Hansen, P.J., Rost, B., 2008. Inorganic carbon acquisition in potentially toxic and non-toxic diatoms: the effect of pH-induced changes in the carbonate chemistry. Physiol. Plant 133, 92-105. doi: 10.1111/j.1399-3054.2007.01038.x.

Wolf-Gladrow, D.A., Riebesell, U., 1997. Diffusion and reaction in the vicinity of plankton: a refined model for inorganic carbon transport. Mar. Chem. 59, 17-34.

Wolf-Gladrow, D.A., Riebesell, U., Burkhardt, S., Bijma, J., 1999. Direct effects of $\mathrm{CO}_{2}$ concentration on growth and isotopic composition of marine phytoplankton. Tellus 51, 461-476.

Wolfstein, K., Hartig, P., 1998. The photosynthetic light dispensation system: application to microphytobenthic primary production. Mar. Ecol. Prog. Ser. 166, 63-71.

Zeebe, R.E., Wolf-Gladrow, D.A., 2001. $\mathrm{CO}_{2}$ in Seawater: Equilibrium, Kinetics, Isotopes. Elsevier Science, Amsterdam.

Zhang, J., Quay, P.D., Wilbur, D.O., 1995. Carbon isotope fractionation during gas-water exchange and dissolution of $\mathrm{CO}_{2}$. Geochim. Cosmochim. Acta 59, 107-114. [SS] 